\title{
Geochemical Characteristics of Late Ordovician Shales in the Upper Yangtze Platform, South China: Implications for Redox Environmental Evolution
}

\author{
Donglin Lin ${ }^{1,2,3}$, Shuheng Tang ${ }^{1,2,3, *}$, Zhaodong $\mathrm{Xi}^{1,2,3}$, Bing Zhang ${ }^{1,2,3}$ and Yapei $\mathrm{Ye}^{1,2,3}$ \\ 1 School of Energy Resource, China University of Geosciences, Beijing 100083, China; \\ lindonglin@cugb.edu.cn (D.L.); xizhaod@cugb.edu.cn (Z.X.); 2106190036@cugb.edu.cn (B.Z.); \\ yeyapei@cugb.edu.cn (Y.Y.) \\ 2 Key Laboratory of Marine Reservoir Evolution and Hydrocarbon Enrichment Mechanism, \\ Ministry of Education, Beijing 100083, China \\ 3 Key Laboratory of Strategy Evaluation for Shale Gas, Ministry of Land and Resources, Beijing 100083, China \\ * Correspondence: tangsh@cugb.edu.cn; Tel.: +86-134-8882-1576
}

\section{check for} updates

Citation: Lin, D.; Tang, S.; Xi, Z.; Zhang, B.; Ye, Y. Geochemical Characteristics of Late Ordovician Shales in the Upper Yangtze Platform, South China: Implications for Redox Environmental Evolution. Minerals 2021, 11, 710. https://doi.org/ $0.3390 / \min 11070710$

\section{Academic Editors:}

Leszek Marynowski and

Alvar Soesoo

Received: 27 May 2021

Accepted: 28 June 2021

Published: 30 June 2021

Publisher's Note: MDPI stays neutral with regard to jurisdictional claims in published maps and institutional affiliations.

Copyright: (c) 2021 by the authors. Licensee MDPI, Basel, Switzerland. This article is an open access article distributed under the terms and conditions of the Creative Commons Attribution (CC BY) license (https:/ / creativecommons.org/licenses/by/ $4.0 /)$.

\begin{abstract}
Changes to the redox environment of seawater in the Late Ordovician affect the process of organic matter enrichment and biological evolution. However, the evolution of redox and its underlying causes remain unclear. This paper analyzed the vertical variability of main, trace elements and $\delta^{34}$ Spy from a drill core section (well ZY5) in the Upper Yangtze Platform, and described the redox conditions, paleoproductivity and paleoclimate variability recorded in shale deposits of the P. pacificus zone and M. extraordinarius zone that accumulated during Wufeng Formation. The results showed that shale from well ZY5 in Late Ordovician was deposited under oxidized water environment, and there are more strongly reducing bottom water conditions of the M. extraordinarius zone compared with the P. pacificus zone. Excess silica $\left(\mathrm{SiO}_{2(\mathrm{exc})}\right)$ and substitution index of paleoproductivity $(\mathrm{Y})$ indicated that the $P$. pacificus zone had higher paleoproductivity whereas the $M$. extraordinarius zone was lower. The high productivity level controlled $\mathrm{O}_{2}$ release in the shallow water area as well as the oxidation degree of the P. pacificus zone. The decrease of productivity and the relatively stagnant water mass of the inner Yangtze Sea controlled the formation of relatively reduced water conditions in the M. extraordinarius zone. The chemical index of alteration (CIA) results suggested that palaeoclimatic conditions changed from warm and humid to cold and dry climate from the $P$. pacificus to the M. extraordinarius zones in the study area. A comparative analysis of the published Fe-S-C data for the Xiushan Datianba section showed that in the P. pacificus zone of the inner Yangtze Sea, warm and humid climate conditions drove high productivity, sulphate flux and low reactive iron flux, which promoted the expansion of oxic ocean-surface waters and mid-depth euxinic waters. In the M. extraordinarius zone, the cold and dry climate with significant uplift of the Xiang'e Submarine High led to the relative sea level decline, resulting in low productivity, sulfate flux and high reactive iron flux, which promoted the expansion of the mid-depth ferruginous waters and the shrinkage of oxic ocean-surface waters. The results offered new insights into the co-evolution of continents and oceans, and explained the role of continental weathering and uplift of the Xiang'e Submarine High in the exchange of sulfate flux and nutrients in the redox environment change of inner Yangtze Sea during the Late Ordovician.
\end{abstract}

Keywords: inner Yangtze sea; Late Ordovician; paleoclimatic; paleoredox; paleoproductivity

\section{Introduction}

The Late Ordovician is an important transition period in geological history, accompanied by large-scale glaciation, volcanism, sea level change, local tectonic activities and other geological and biological extinction events [1-3]. The Wufeng-Longmaxi Formation is widely distributed in the Yangtze platform, and is an important stratigraphic record 
of geological events and an exceptional hydrocarbon source for commercial oil and gas exploration and production in South China [4]. The change of redox environment in the Late Ordovician had a significant effect on the accumulation of organic matter and the biotic extinction event. Therefore, the evolution of the organic-rich shale sedimentary environment during the Ordovician-Silurian transition has become a focus of recent research efforts [5-7].

Recent studies have suggested that the Ordovician-Silurian oceans may have been made up of mid-depth euxinic waters dynamically sandwiched between surface oxic and deep ferruginous waters [3,8-10]. The spatial heterogeneity of the redox environment in the Yangtze Sea during the Late Ordovician is largely related to the global climate change (e.g., the Hirnantian Glaciation) and tectonic activity (e.g., the Kwangsian Orogeny) [5,8]. It has been confirmed that the expansion of mid-depth marine euxinia was related to the uneven spatial distribution of sulfate contents in the inner Yangtze sea during the late Ordovician [10]. However, the spatiotemporal evolution mechanism of the redox environment is still unclear, and many important factors including continental weathering have not been taken into consideration. The change in oxic ocean-surface and mid-depth euxinic waters is believed to have influenced the change of palaeoproductivity and sulfate flux $[1,11,12]$ in response to both tectonic and palaeoclimate changes.

To analyze the redox environment evolution and its controlling factors from the inner Yangtze Sea in the Late Ordovician, this study will focus on Wufeng Formation shale from Well ZY5 deposited in the southwest margin of the Xiang'e Submarine High as the research object. The $\mathrm{Si}, \mathrm{Cu}, \mathrm{Ni}$ and $\mathrm{Zn}$ proxies are used for oceanic primary productivity evaluation [13]. A combination of independent geochemical proxies (i.e., redox-sensitive trace elements Mo and $U$, pyrite $\delta^{34} S$ compositions $\left(\delta^{34} S_{p y}\right)$ ) and pyrite framboid size distribution data are used to reconstruct the redox conditions of the bottom water [14-16]. Then, we made a comprehensive analysis of the paleoclimate conditions. By comparing Fe-S-C results with published data from the Datianba section [8], we aimed to provide a new insight of the heterogeneity of climate change and tectonic activity on the redox environment evolution in the inner Yangtze Sea during the Late Ordovician.

\section{Geologic Setting}

The South China Plate was an isolated microcontinent attached to the northwestern margin of Gondwana in Late Ordovician (Figure 1a) [17]. The Yangtze Platform was located in the middle of the South China Plate and was covered by a vast continental margin sea. Due to the influence of the Kwangsian Orogeny, the Cathaysia plate collided with the Yangtze plate from southeast to northwest, resulting in the uplift of the Qianzhong Oldland and Xiang'e Submarine High [18]. The Yangtze Sea was divided into inner Yangtze Sea and outer Yangtze Sea [19], forming a paleogeographic pattern with "one uplift and three depressions" surrounded by oldlands on three sides (Figure 1b). Due to the relatively weak connectivity between the inner and outer seas, the inner Yangtze Sea was semi-restricted with anoxic and low-energy bottom waters [1,8,10].

Well ZY5 and the Xiushan Datianba section are located in the inner Yangtze Sea. Datianba was near the northeastern margin of the Qianzhong oldland, and well ZY5 was located in the southwest margin of the Xiang'e Submarine High (Figure 1b). Two sections contain the Upper Ordovician Wufeng Formation, which are dominantly black shale containing a large number of spongy spicules and radiolarian fossils [20]. The Wufeng Formation of the Datianba section was continuously deposited, whereas well ZY5 near the Xiang'e Submarine High was missing the late Hirnantian stage strata. Under the influence of Kwangsian Orogeny, the Cathaysia oldland gradually advanced to the northwest during the late Ordovician, which resulted in the intensification of the uplift of the Xiang'e Submarine High. The Submarine High and surrounding areas were subjected to different degrees of denudation [21].

Chen et al. [22] used graptolites fossils from Late Ordovician-Early Silurian transition profiles in South China and their stratigraphic correlation to establish regional and global 
biological zoning programmes. The Dicellograptus Complexus graptolite zone, Paraorthograptus pacificus graptolite zone and Metabolograptus extraordinarius graptolite zone developed in the Wufeng Formation of the Late Ordovician. Well ZY5 is based on graptolite characteristics and the GR curve recognition method proposed by $\mathrm{Xi}$ et al. [23] can identify the range from $2016 \mathrm{~m}$ to $2010 \mathrm{~m}$ as the Paraorthograptus pacificus graptolite zone (hereafter referred to as the P. pacificus zone). From $2010 \mathrm{~m}$ to $2096 \mathrm{~m}$ is the Metabolograptus extraordinarius graptolite zone (the M. extraordinarius zone) (Figure 1c).

a Late Ordovician(440 Ma)
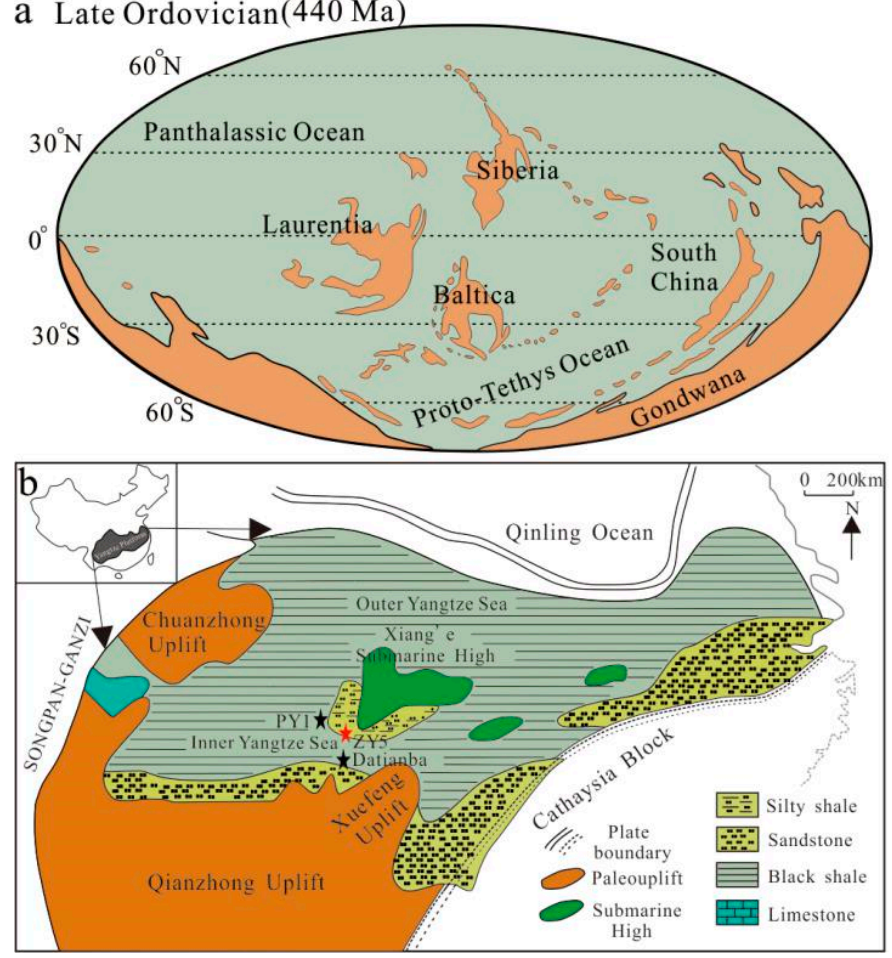

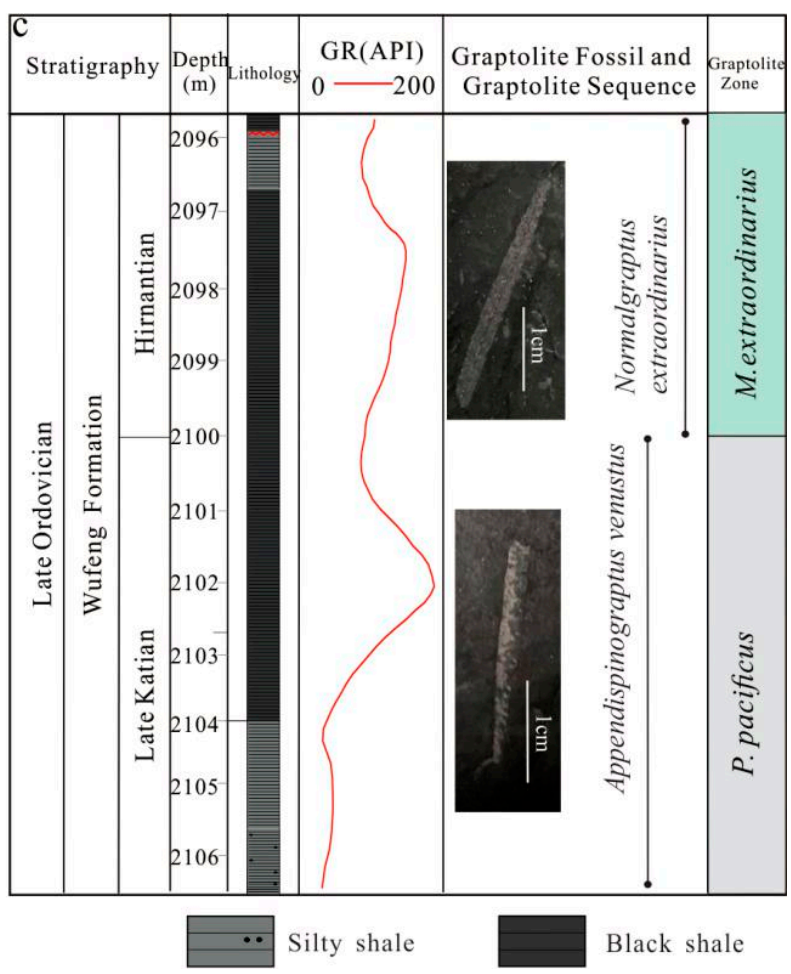

Figure 1. (a) Late Ordovician global paleogeography in South China (Modified after [2]); (b) Paleogeography of Yangtze Sea during the Late Ordovician (Modified after [1]); (c) Biostratigraphic division of Well ZY5 (Modified after [24]). Paraorthograptus pacificus $=$ P. pacificus, M. extraordinarius = Metabolograptus extraordinarius.

\section{Materials and Analytical Methodology}

\subsection{Samples and Experimental Methods}

A total of 16 fresh core samples were collected from Well ZY5 and weathered surfaces of samples were removed prior to analysis, and then washed and dried. Core samples were analyzed for TOC, sulfur contents of pyrite $\left(S_{p y}\right), \delta^{34} S_{p y}$, major and trace elements, reactive iron $\left(\mathrm{Fe}_{\mathrm{HR}}\right)$ and pyrite particle size statistics. All analyses were carried out at the State Key Laboratory of Biogeology and Environmental Geology, China University of Geosciences (Wuhan).

For TOC analysis, approximately $100 \mathrm{~g}$ sample finer than 80 mesh size was treated with hydrochloric acid $\left(1: 7 \mathrm{HCl}\right.$ : water) at $50^{\circ} \mathrm{C}$ to remove the carbonates, neutralized until to a $\mathrm{pH}$ of 7.0 by adding distilled water, then the sample was transferred to a porcelain crucible and dried in an oven for testing and analysis using a Jena Eltra 4000 carbon-sulfur analyzer (Jena, Germany). The analytical error of TOC measurements was better than $0.2 \%$. Pyrite framboids were measured using a scanning electron microscope (Hitachi-SU8010) (Hitachi, Tokyo, Japan). A size population more than 100 pyrite framboids were selected to measure diameters. Our methodology of pyrite particle size analysis is described in $\mathrm{Xi}$ et al. $[24,25]$.

For major-element analysis (e.g., $\mathrm{Al}, \mathrm{P}$, and $\mathrm{Si}$ ), the predried sample powders of smaller than 200 mesh were selected calcined for $4 \mathrm{~h}$ in a $1000{ }^{\circ} \mathrm{C}$ high-temperature 
furnace to remove organics. Approximately $0.5 \mathrm{~g}$ of calcined sample was treated with anhydrous lithium tetraborate (eight times the sample mass), $0.4 \mathrm{~g}$ lithium fluoride and $0.3 \mathrm{~g}$ ammonium nitrate, accurately weighed into a porcelain crucible. After being completely mixed, the mixture was transferred to a platinum crucible, treated with a lithium bromide solution and placed on an electric hot plate for drying. The crucible was subsequently fused at $1150{ }^{\circ} \mathrm{C}$ with an automatic flame melting to form a borate glass disks, and then measured by X-ray fluorescence spectrometry with a test accuracy deviation of less than $3 \%$.

For trace elements analysis (e.g., Mo and U), samples ( $0.5 \mathrm{~g})$ of smaller than 200 mesh particle size were placed in crucibles and calcined for $4 \mathrm{~h}$ in a $700{ }^{\circ} \mathrm{C}$ high-temperature furnace to remove organics. Approximately $40 \mathrm{mg}$ of calcined sample were dissolved using a standard multi-acid digestion ( $\left.\mathrm{HF}-\mathrm{HNO}_{3}-\mathrm{HCl}\right)$. The solution was diluted in $2 \%$ $\mathrm{HNO}_{3}$ and measured using inductively coupled plasma mass spectrometry (ICP MS) (Nu Instruments, Wrexham, UK) with a test accuracy deviation of less than $5 \%$.

Highly reactive $\mathrm{Fe}\left(\mathrm{Fe}_{\mathrm{HR}}\right)$ is contained in carbonate iron $\left(\mathrm{Fe}_{\mathrm{carb}}\right)$, oxide/hydroxide iron $\left(\mathrm{Fe}_{\mathrm{ox}}\right)$, magnetite iron $\left(\mathrm{Fe}_{\mathrm{mag}}\right)$, and pyrite $\left(\mathrm{Fe}_{\mathrm{py}}\right)$. The pyrite iron concentration $\left(\mathrm{Fe}_{\mathrm{py}}\right)$ and pyrite sulfur $\left(\mathrm{S}_{\mathrm{py}}\right)$ was extracted by using the chromium reduction method described by Canfield et al. [26]. Powdered samples were treated with an acidified $\mathrm{CrCl}_{2}$ solution, the liberated hydrogen sulfide was trapped by silver-nitrate solution through precipitation as $\mathrm{Ag}_{2} \mathrm{~S} . \mathrm{Fe}_{\mathrm{py}}$ and $\mathrm{S}_{\text {py }}$ was then gravimetrically calculated. $\mathrm{Fe}_{\text {carb }}, \mathrm{Fe}_{\mathrm{ox}}$ and $\mathrm{Fe}_{\mathrm{mag}}$ were determined using the sequential extraction procedure of Poulton and Canfield [27]. All concentrations of extracted iron speciation were diluted to a suitable concentration with $2 \%$ $\mathrm{HNO}_{3}$ and tested by atomic absorption spectrometry (AAS); analytical errors were under $5 \%$.

For $\delta^{34} \mathrm{~S}_{\text {py }}$ analysis, the $\mathrm{Ag}_{2} \mathrm{~S}$ precipitates from pyrite extractions were combusted with excess of $\mathrm{V}_{2} \mathrm{O}_{5}$ in preparation for measurement of its $\mathrm{S}$-isotopic composition $\left(\delta^{34} \mathrm{~S}_{\text {py }}\right)$. Isotope measurements were made using an elementary analyzer-stable isotope ratio mass spectrometer (EA-IRMS) (Finnigan MAT, Bremen, Germany), and the sulfur isotope adopted the V-CDT standard with accuracy better than $\pm 0.2 \%$. based on replicate analyses of standards IAEA S1 $\left(\delta^{34} \mathrm{~S}=-0.3 \%\right)$, IAEA S2 $\left(\delta^{34} \mathrm{~S}=+22.65 \%\right)$ and IAEA S3 $\left(\delta^{34} \mathrm{~S}=-32.5 \%\right)$.

\subsection{Background: Proxies Used in this Study \\ 3.2.1. Paleoredox Proxies}

The concentrations and enrichment characteristics of Mo and $\mathrm{U}$ are often used to reconstruct the redox environment. Mo exists in molybdate anion $\left(\mathrm{MO}_{4}{ }^{2-}\right)$ form in oxic water columns, and is converted to particle-reactive thiomolybdates $\left(\mathrm{MoS}_{4-\mathrm{x}} \mathrm{O}_{\mathrm{x}}{ }^{2-}, \mathrm{x}=1-4\right)$ in euxinic environments. In the latter form, it can be taken up by Fe-Mo-S nano-minerals or organo-metallic ligands in organic matter, resulting in high abundances in the sediment [28]. Therefore, strong enrichments of Mo are a salient characteristic of euxinic depositional environment. $\mathrm{U}$ is dissolved in water as $\mathrm{U}^{6+}\left(\mathrm{UO}_{2}\left(\mathrm{CO}_{3}\right)_{3}{ }^{4-}\right)$ in oxic and suboxic water environments, and is converted to $\mathrm{U}^{4+}$ around the $\mathrm{Fe}(\mathrm{II})-\mathrm{Fe}(\mathrm{III})$ redox boundary $[13,14]$. Reduced $\mathrm{U}$ is usually insoluble and easily adsorbed by sediments. Consequently, strong enrichments of $U$ indicate an anoxic environment, whereas lower enrichments of these trace metals are consistent with an oxic-suboxic water environment [13]. Trace-metal enrichment factors $(\mathrm{EF})$ were calculated as: $\mathrm{X}_{\mathrm{EF}}=(\mathrm{X} / \mathrm{Al})_{\text {sample }} /(\mathrm{X} / \mathrm{Al})_{\mathrm{PAAS}} ; \mathrm{X}_{\mathrm{EF}}>3$ was interpreted to reflect detectable enrichment relative the average shale, while $X_{\mathrm{EF}}<1$ indicates the depletion concentrations. In the modern ocean, Mo concentrations greater than $100 \mathrm{ppm}$ represent an euxinia environment, concentrations between 25 and $100 \mathrm{ppm}$ represent an intermittent euxinia environment, and concentrations less than $25 \mathrm{ppm}$ represent a non-euxinic environment [29].

$\mathrm{U} / \mathrm{Th}$ and $\mathrm{C}_{\mathrm{org}} / \mathrm{P}_{\text {total }}$ indexes are positively correlated with the redox environment, which always increase with the increase of water anoxic degree. The U/Th ratio is usually greater than 1.25 in an anoxic environment, between 0.75 and 1.25 in a suboxic environment, and less than 0.75 in an oxic water column environment [30]. Algeo and Ingall [31] proposed 
that $\mathrm{C}_{\text {org }} / \mathrm{P}_{\text {total }}$ less than 50 reflects an oxic water column environment, between 50 and 200 represents a suboxic water column environment, and greater than 200 suggests anoxic.

The size distribution of pyrite framboids has been used to determine water-column redox conditions in modern and ancient sedimentary basins, and is largely controlled by growth time and rate. The mean size and standard deviation of pyrite can reflect the redox environment of the ancient ocean [16,32]. In an oxic water environment, pyrite can only be formed under the redox interface. Sulfate in the water column is continuously reduced by sulfate-reducing bacteria to form hydrogen sulfide $\left(\mathrm{H}_{2} \mathrm{~S}\right)$ under the redox interface. Since hydrogen sulfide $\left(\mathrm{H}_{2} \mathrm{~S}\right)$ and elemental Fe are continuously supplied in small amounts, they have a relatively slow growth rate and longer growth time, resulting in framboids with sizes greater than $7.7 \pm 4.1 \mu \mathrm{m}$. In anoxic water environments, framboids may form within the water column near the redox interface. Since the environment is rich in ferrous ions and $\left(\mathrm{H}_{2} \mathrm{~S}\right)$ and there is no sediment support, it will soon sink into the ocean floor. Therefore, framboids are unable to achieve diameters much greater than $5.0 \pm 1.7 \mu \mathrm{m}$ [32].

\subsubsection{Paleoproductivity Proxies}

Nutrient elements $(\mathrm{Cu}, \mathrm{Ni}$ and $\mathrm{Zn})$ in sediments can be used to reconstruct paleoproductivity. This is because oceanic primary productivity in the euphotic zone is significantly influenced by the availabilities of nutrient elements in seawater, and their concentrations decrease from the surface to the deep sea [33,34], which is finally buried in the sediments together with the sinking organic matter. Therefore, their sedimentary enrichments can also be used to infer the oceanic primary productivity. Generally speaking, the synthetic substitution of multiple elements is more reliable than that of a single element as a productivity indicator. Chen et al. [35] used principal component analysis to construct the substitution index of paleoproductivity including excess copper $\left(\mathrm{Cu}_{\mathrm{Xs}_{\mathrm{s}}}\right)$, excess nickel $\left(\mathrm{Ni}_{\mathrm{Xs}}\right)$ and excess zinc $\left(\mathrm{Zn}_{\mathrm{X}_{\mathrm{s}}}\right)$ to indicate the paleoproductivity strength. The calculation is as follows:

$$
\mathrm{Y}=0.593955 \mathrm{w}\left(\mathrm{Cu} \mathrm{XS}_{\mathrm{S}}\right)+0.523396 \mathrm{w}\left(\mathrm{Ni}_{\mathrm{XS}}\right)+0.610962 \mathrm{w}\left(\mathrm{Zn}_{\mathrm{XS}}\right)
$$

where $X_{X S}$ represents the excess value of trace elements (e.g., $\mathrm{Cu}$ and $\mathrm{Ni}$ ), the correction formula is written as: $X_{X s}=X_{\text {total }}-\mathrm{Ti}_{\text {total }} \times(X / T i)_{\text {PAAS }}, X_{\text {total }}$ and $\mathrm{Ti}_{\text {total }}$ represent the elements to $X$ and Ti sample values, respectively, and $(X / \mathrm{Ti})_{\text {PAAS }}$ represents the ratio of element to $\mathrm{Ti}$ in post-Archean Australian Shale (PAAS).

Excess silica $\left(\mathrm{SiO}_{2(\mathrm{exc})}\right)$ refers to the silicon of the non-clay origin and is used to characterize the biogenic silicate portion [36]. The calculation is as follows:

$$
\mathrm{SiO}_{2(\mathrm{exc})}=\left[\mathrm{SiO}_{2}\right]_{\text {sample }}-\left[\mathrm{Al}_{2} \mathrm{O}_{3}\right]_{\text {sample }} \times\left(\mathrm{SiO}_{2} / \mathrm{Al}_{2} \mathrm{O}_{3}\right)_{\text {debris }}
$$

where $\left(\mathrm{SiO}_{2} / \mathrm{Al}_{2} \mathrm{O}_{3}\right)_{\text {debris }}=2.28$ is based on the content of major elements relationships. [SiO2 $]_{\text {sample }}$ and $\left[\mathrm{Al}_{2} \mathrm{O}_{3}\right]_{\text {sample }}$ represent sample $\mathrm{SiO}_{2}$ and $\mathrm{Al}_{2} \mathrm{O}_{3}$ values, respectively. Specifically, $\mathrm{CaO}$ and $\mathrm{Al}_{2} \mathrm{O}_{3}$ have a moderate negative correlation when the intercept of the $\mathrm{x}$-axis is $22.3 \%$, which reflects the $\mathrm{Al}_{2} \mathrm{O}_{3}$ content in the pure shale portion of the study area (Figure 2a). When $\mathrm{Al}_{2} \mathrm{O}_{3}$ is $22.3 \%$, based on the $\mathrm{SiO}_{2}$ vs. $\mathrm{Al}_{2} \mathrm{O}_{3}$ crossplot the pure shale fraction of $\mathrm{SiO}_{2}$ content is estimated to be $50.8 \%$ (Figure $2 \mathrm{~b}$ ). 

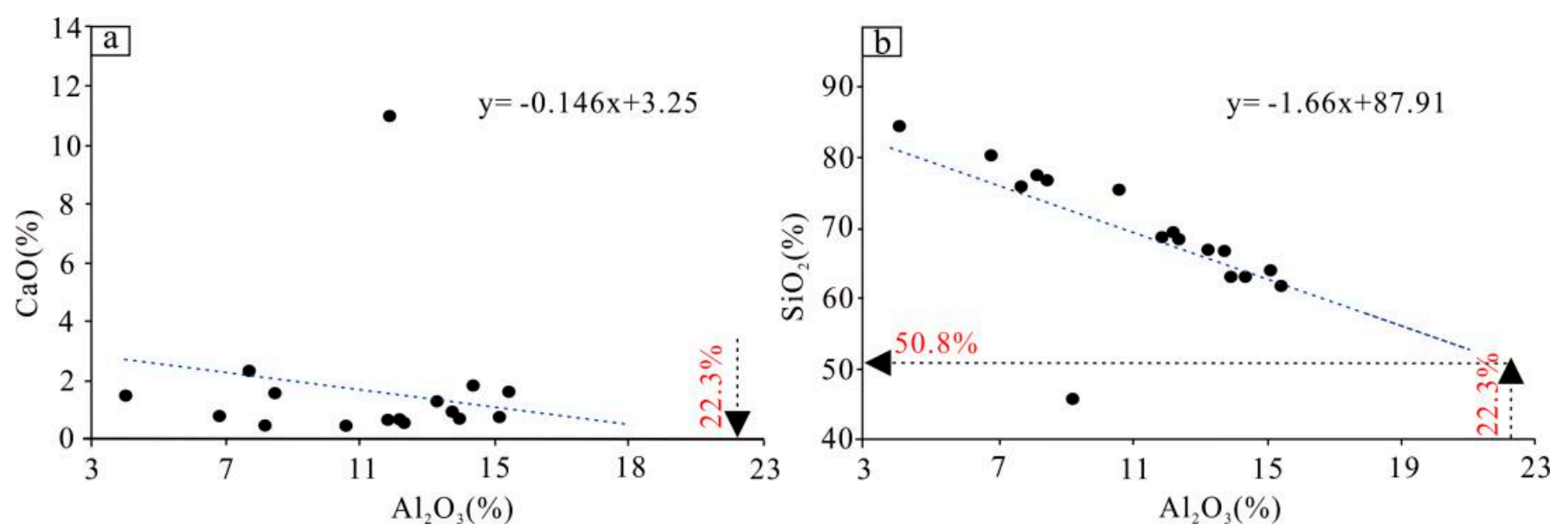

Figure 2. Correlations between $\mathrm{CaO}$ vs $\mathrm{Al}_{2} \mathrm{O}_{3}(\mathbf{a})$, and $\mathrm{SiO}_{2}$ vs $\mathrm{Al}_{2} \mathrm{O}_{3}$ (b) from well $\mathrm{ZY} 5$. One outlier with high carbonate content $(\mathrm{CaO}=11.1 \%)$ was not viewed as representative.

\subsubsection{Paleoclimate Proxies}

The chemical alteration index (CIA) was developed to reflect provenance chemical weathering intensity $[37,38]$. In recent years, it has been applied to study paleoclimate change in the process of sedimentation [39].

$$
\mathrm{CIA}=\mathrm{Al}_{2} \mathrm{O}_{3} /\left(\mathrm{Al}_{2} \mathrm{O}_{3}+\mathrm{CaO}^{*}+\mathrm{Na}_{2} \mathrm{O}+\mathrm{K}_{2} \mathrm{O}\right) \times 100
$$

In the formula, the unit of each oxide is the mole fraction, and $\mathrm{CaO}^{*}$ represents $\mathrm{CaO}$ of composition silicate mineral fraction [40]. Therefore, it is necessary to calibrate $\mathrm{CaO}$ in carbonate minerals (calcite and dolomite) and phosphate minerals (apatite). This paper used phosphate for $\mathrm{CaO}$ calibration according to the formula $\mathrm{CaO}^{*}=\mathrm{CaO}-\mathrm{P}_{2} \mathrm{O}_{5} \times 10 / 3$. If the number of moles of $\mathrm{CaO}^{*}$ obtained was less than the number of moles $\mathrm{of} \mathrm{Na}_{2} \mathrm{O}$, the calculated value was used to replace $\mathrm{CaO}^{*}$, If the mole number of $\mathrm{CaO}^{*}$ was greater than the mole number of $\mathrm{Na}_{2} \mathrm{O}$, the mole number of $\mathrm{Na}_{2} \mathrm{O}$ was used instead of $\mathrm{CaO}^{*}$ [41] Additionally, $\mathrm{K}_{2} \mathrm{O}$ was further corrected for $\mathrm{K}$-metasomatism and metamorphism of the source rocks: $\mathrm{K}_{2} \mathrm{O}_{\text {corr }}=\operatorname{molar}\left[\mathrm{m} \times \mathrm{Al}_{2} \mathrm{O}_{3}+\mathrm{m} \times\left(\mathrm{CaO} *+\mathrm{Na}_{2} \mathrm{O}\right)\right] /(1-\mathrm{m})$, where $\mathrm{m}=$ $\mathrm{K} 2 \mathrm{O} /\left(\mathrm{Al}_{2} \mathrm{O}_{3}+\mathrm{CaO} *+\mathrm{Na}_{2} \mathrm{O}+\mathrm{K}_{2} \mathrm{O}\right)$ [42]. Generally speaking, a CIA of $50 \sim 65$ represents a low degree of chemical weathering intensity in cold or arid climate conditions. CIA values of 65 85 indicate moderate chemical weathering intensity in warm and humid climate conditions. CIA values of $85 \sim 100$ suggest strong chemical weathering intensity in hot and humid climate conditions [37].

\section{Results}

\subsection{Paleoredox Data}

The $\mathrm{U} /$ Th and $\mathrm{C}_{\text {org }} / \mathrm{P}_{\text {total }}$ ratios have a similar vertical trend in well $\mathrm{ZY5}$. $\mathrm{U} /$ Th values ranged from 0.15 0.31(mean 0.22) in the P. pacificus zone and increased to $0.21 \sim 0.48$ (mean 0.33 ) in the M. extraordinarius zone. $C_{\text {org }} / P_{\text {total }}$ ratios are bteween 5.50 13.79 (mean 9.94) in the P. pacificus zone and increased with significant fluctuations to $7.20 \sim 15.20$ (mean 11.13) in the M. extraordinarius zone.

The concentrations and enrichment factors of $\mathrm{Mo}$ and $\mathrm{U}$ have broadly similar trends as the $\mathrm{U} / \mathrm{Th}$ and $\mathrm{C}_{\text {org }} / \mathrm{P}_{\text {total }}$ ratios (Figure 3). The P. pacificus zone exhibited extremely low values: $\mathrm{Mo}=0.39 \sim 0.84 \mathrm{ppm}($ mean $0.57 \mathrm{ppm}), \mathrm{U}=1.12 \sim 5.26 \mathrm{ppm}($ mean $=2.78 \mathrm{ppm})$, and $\mathrm{Mo}_{\mathrm{EF}}=0.87 \sim 2.35$ (mean 1.34), $\mathrm{U}_{\mathrm{EF}}=0.42 \sim 0.87$ (mean 0.63). The $M$. extraordinarius zone had relatively higher concentrations and enrichment factors compared with the P. pacificus zone: $\mathrm{Mo}=0.53 \sim 6.11 \mathrm{ppm}$ (mean $3.47 \mathrm{ppm}), \mathrm{U}=4.09 \sim 8.72 \mathrm{ppm}$ (mean $6.07 \mathrm{ppm})$, and $\mathrm{Mo}_{\mathrm{EF}}=0.73 \sim 9.98$ (mean 6.23), $\mathrm{U}_{\mathrm{EF}}=0.62 \sim 1.56$ (mean 1.17) (Table S1). 


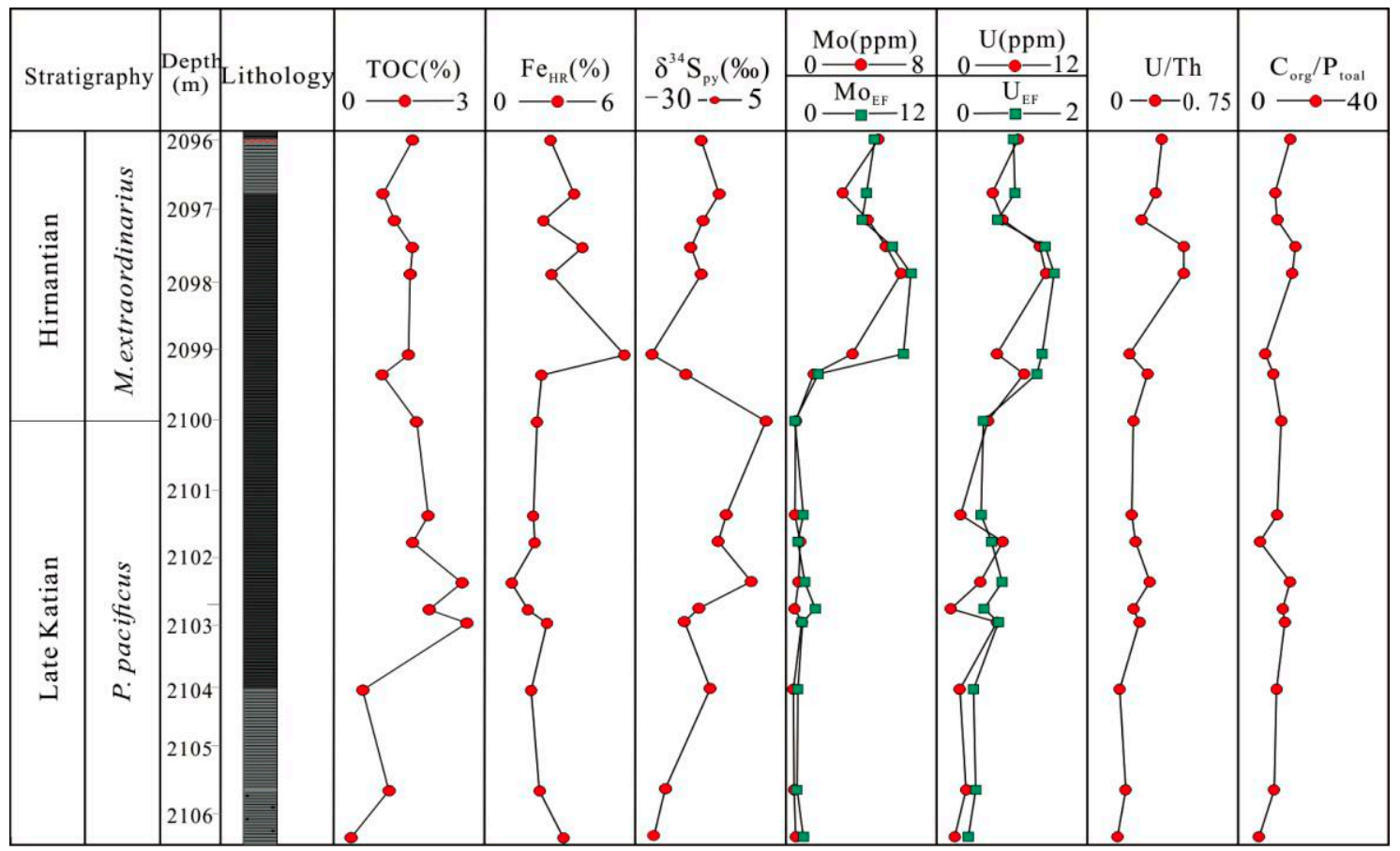

Figure 3. Chemostratigraphic profiles of TOC, $\mathrm{Fe}_{\mathrm{HR}}, \delta^{34} \mathrm{Spy}$, Mo-U concentrations, $\mathrm{Mo}_{\mathrm{EF}}$ and $\mathrm{U}_{\mathrm{EF}}, \mathrm{C}_{\mathrm{org}} / \mathrm{P}_{\text {totl }}$ and $\mathrm{U} / \mathrm{Th}$ of the well ZY5. Lithological legend and abbreviations as in Figure 1.

\subsection{Productivity Data}

The TOC contents vary between $0.17 \%$ 2.28\% (mean $1.29 \%$ ) in the P. pacificus zone, and $0.73 \% \sim 1.35 \%$ (mean $1.07 \%$ ) in the M. extraordinarius zone. The $\mathrm{SiO}_{2(\mathrm{exc})}$ contents first increased, ranging from $29.8 \%$ to $75.4 \%$ (mean $54.8 \%$ ) in the P. pacificus zone, and then decreased ranging from $26.7 \%$ to $41.8 \%$ (mean $33.2 \%$ ) (Figure 4 ). The $Y$ values displayed similar trends as $\mathrm{SiO}_{2(\mathrm{exc})}$, gradually increasing from 77.4 to 216.6 (mean 155.6) in the $P$. pacificus zone, and then decreasing from 63.4 to 150.7 (mean 120.6) in the M. extraordinarius zone (Table S2).

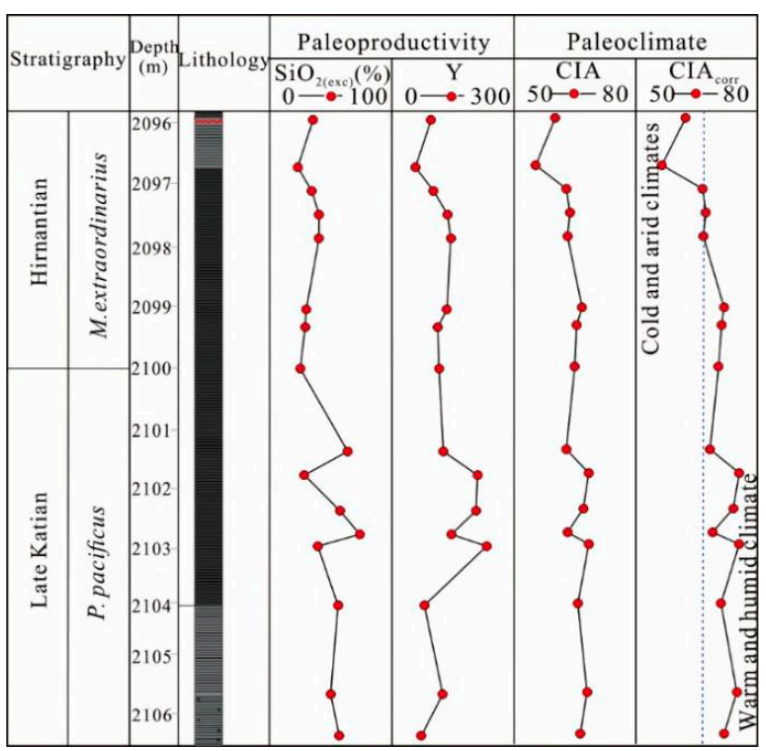

Figure 4. Profiles of $\mathrm{Y}, \mathrm{SiO}_{2(\mathrm{exc})}$ and chemical index of alteration (CIA) values from the well ZY5. Vertical dashed lines show the approximate ranges between cold or arid climate conditions, and warm and humid climate conditions. Lithological legend and abbreviations as in Figure 1. 


\subsection{Sulfur Content and $\delta^{34} S_{p y}$ and Framboidal Pyrite Size Distribution}

The sulfur contents of pyrite $\left(\mathrm{S}_{\mathrm{py}}\right)$ range between $0.11 \% \sim 5.31 \%$ (mean $1.12 \%$ ) in well ZY5. Deposits of the P. pacificus zone are bteween $0.11 \% \sim 0.72 \%$ (mean $0.45 \%$ ), gradually increasing to $0.78 \% \sim 5.31 \%$ (mean $1.89 \%$ ) in the M. extraordinarius zone (Table S1). $\delta^{34} \mathrm{~S}_{\mathrm{py}}$ values range between $-24.83 \%$ to $-3.61 \%$ in the P. pacificus zone, in the M. extraordinarius zone they decreased from $-0.36 \%$ to $-25.19 \%$ in the early stage and increased to $-10.57 \%$ o in the middle stage (Figure 3).

Size distribution analysis for in the early of the P. pacificus zone was not done due to lack of pyrite. In the middle and late stages of the P. Pacificus zone pyrite framboids were generally large with mean sizes ranging from $5.6 \mu \mathrm{m}$ to $6.5 \mu \mathrm{m}$ (standard deviations = $1.8 \mu \mathrm{m}$ ). It is noteworthy that irregular, large pyrite is present in these deposits (Figure 5a). The M. extraordinarius zone pyrite framboids had smaller grain sizes with mean sizes ranging from $5.5 \mu \mathrm{m}$ to $7.2 \mu \mathrm{m}$ (standard deviations $=3.2 \mu \mathrm{m}$ ) (Figure 6). Relatively small pyrite framboids and massive pyrite are present in M. extraordinarius zone deposits (Figure $5 b, c)$.

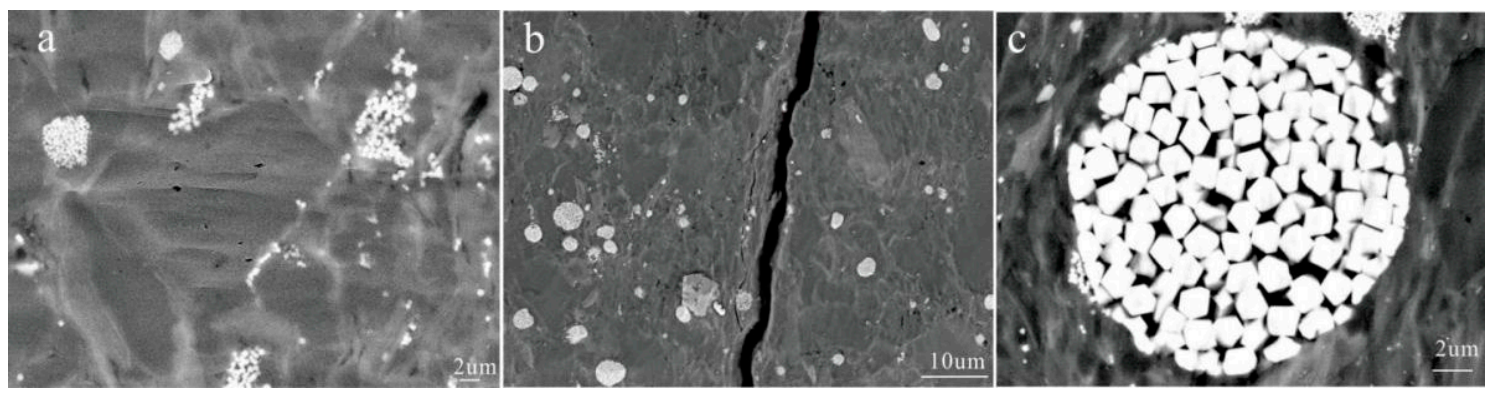

Figure 5. Morphological characteristics of pyrite in the shale samples of Well ZY5: (a) euhedral pyrite aggregate, sample of P. pacificus zone; $(\mathbf{b}, \mathbf{c})$ Pyritohedral microcrystals in tiny framboidal pyrite, sample of $M$. extraordinarius zone.

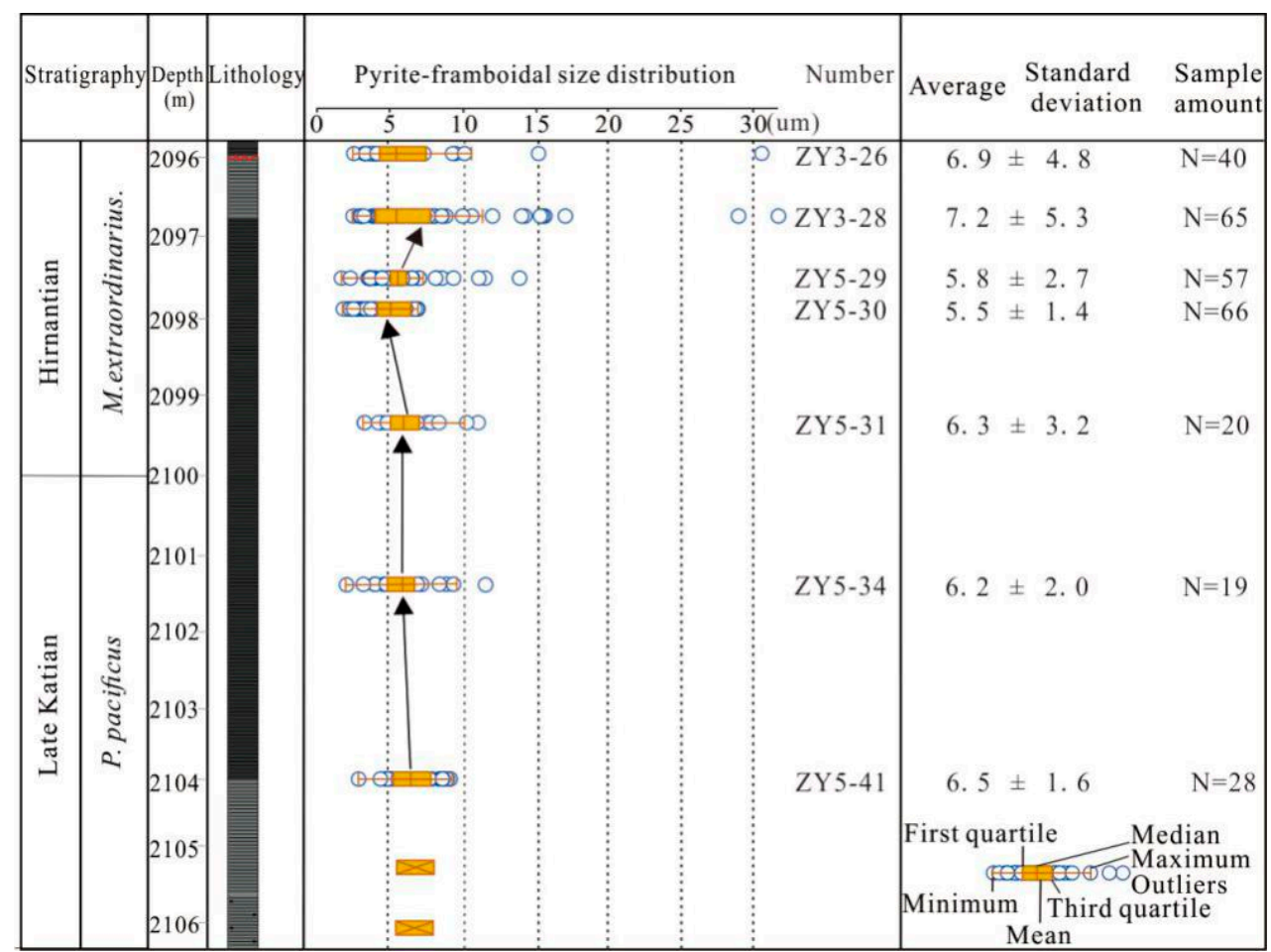

Figure 6. Pyrite framboid size distribution and 'box and whisker' plots from Late Ordovician shale in well ZY5. Lithological legend and abbreviations as in Figure 1. 


\subsection{Paleoclimatic Data}

A triangle map of A-CN-K can indicate the chemical weathering trend and the change of original composition and mineral characteristics during weathering [37]. In the process of weathering, plagioclase is weathered more easily than potassium feldspar, resulting in a higher loss rate of $\mathrm{Ca}$ and $\mathrm{Na}$ elements than the $\mathrm{K}$ elements. Therefore, the weathering trend lines of rocks without potassium metasomatism and diagenetic transformation are parallel to the A-C-N line in the ternary diagram.

The projection points of the samples in the study area deviated from the original weathering trend line (center line a in Figure 7d), indicating that shale in Well ZY5 experienced a certain amount of potassium metasomatism. After correction, the CIA $\mathrm{A}_{\text {corr }}$ values were higher and relatively stable in the P. pacificus zone, fluctuating between 68.7 and 75.9 (mean $=72.9$ ). Further upwards, CIA values declined, ranging from 59.9 to 72.2 (mean $=67.6)$ in the M. extraordinarius zone (Figure 4, Table S2).

a

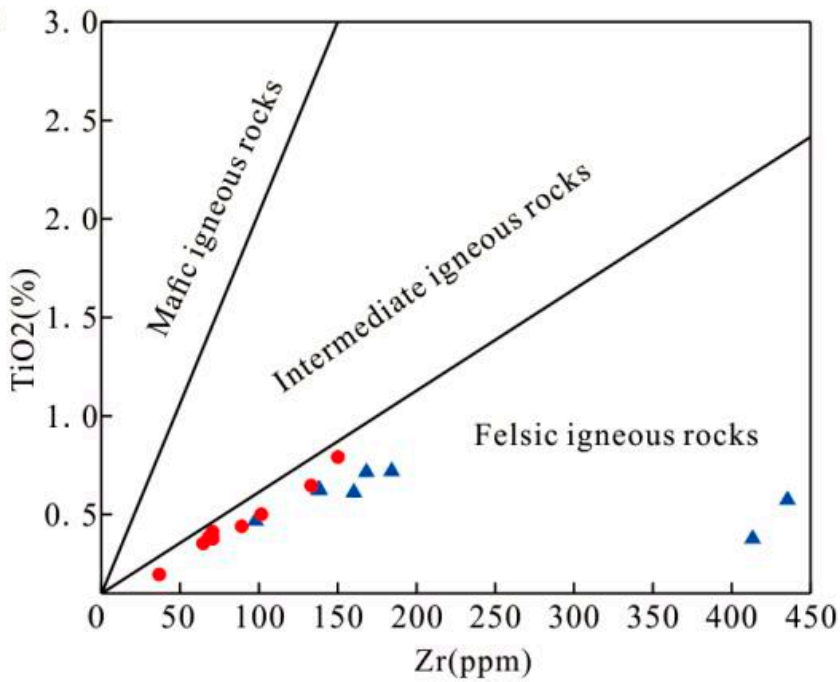

$\mathrm{c}$

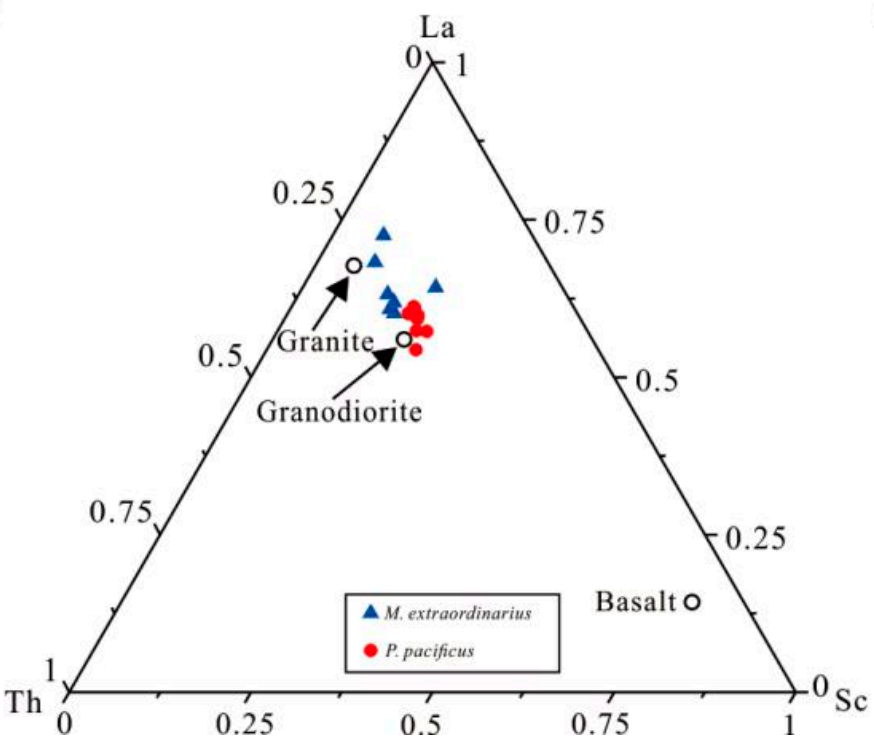

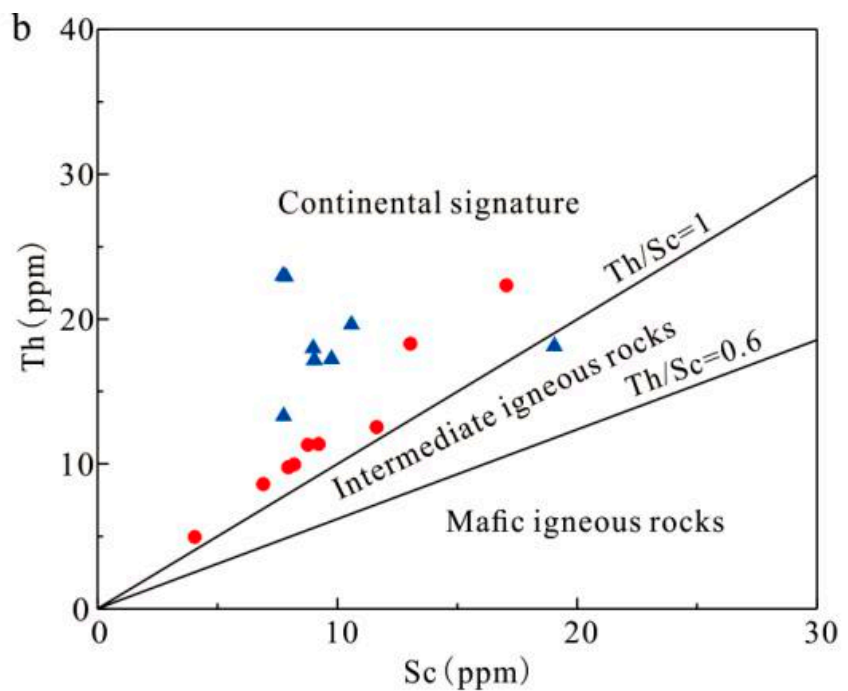

d

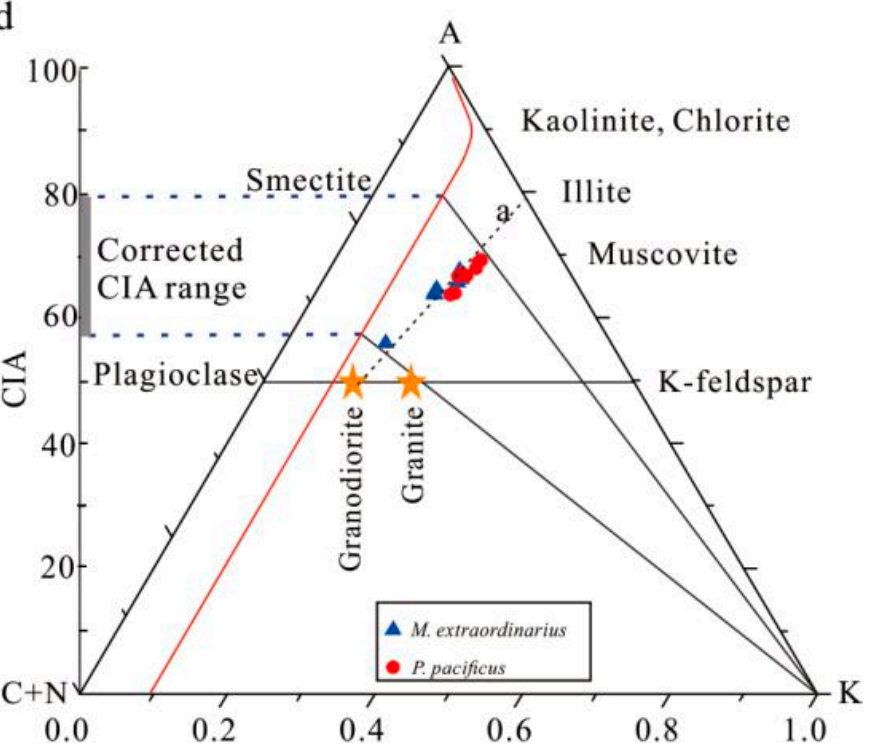

Figure 7. (a) Crossplot of $\mathrm{TiO}_{2}$ versus $\mathrm{Zr}$; (b) Crossplot of Th versus Sc; (c) La-Sc-Th ternary diagram showing source rock types from Well ZY5 and (d) A-CN-K $\left(\mathrm{Al}_{2} \mathrm{O}_{3-}\left(\mathrm{CaO}^{*}+\mathrm{Na}_{2} \mathrm{O}\right)-\mathrm{K}_{2} \mathrm{O}\right)$ ternary diagram showing diagenetic $\mathrm{K}$-metasomatism and the chemical index of alteration (CIA) ranges for different chemical weathering degrees. 


\section{Discussion}

\subsection{Reconstruction of Redox Environments at Well ZY5 during the Late Ordovician}

The $\mathrm{U} / \mathrm{Th}$ and $\mathrm{C}_{\text {org }} / \mathrm{P}_{\text {total }}$ data suggested that the shale from the P. pacificus zone were deposited in an oxic water column environment. An interpretation consistent with changes of pyrite framboid sizes, the dearth of pyrite framboids in early stage (at depth 2105-2106 m), and then the presence of abundant large pyrite framboids in late stage (at depth 2101-2104 m) (Figure 6). The enrichment characteristics and concentrations of Mo and $\mathrm{U}$ were similar to crustal values $\left(\mathrm{Mo}_{\mathrm{EF}}=1.34, \mathrm{U}_{\mathrm{EF}}=0.63 ; \mathrm{Mo}=0.57 \mathrm{ppm}, \mathrm{U}=2.78\right.$ ppm; Figure 3), which further implicated an oxic water column environment during the $P$. pacificus zone deposition.

The distribution of M. extraordinarius zone data on $\mathrm{U} / \mathrm{Th}$ and $\mathrm{C}_{\text {org }} / \mathrm{P}_{\text {total }}$ ratios showed that deposition occurred under an oxic-suboxic environment (Figure 3), and it was a more reducing bottom water environment compared with deposition of the P. pacificus zone. This was consistent with the presence of abundant relatively small pyrite framboids (Figure 6). Mo and U showed obvious enrichment characteristics relative to crustal values in the M. extraordinarius zone $\left(\mathrm{Mo}_{\mathrm{EF}}=6.23, \mathrm{U}_{\mathrm{EF}}=1.17\right.$; Figure 3), Overall, well ZY5 shifted toward a more reduction water column environment from the P. pacificus zone to the $M$. extraordinarius zone.

\subsection{Mechanisms Controlling the Paleoredox Environment \\ 5.2.1. Paleoproductivity}

The significant increase of ocean surface productivity promoted the downward migration of the redox interface and intensification of bottom-water anoxia [12]. $\mathrm{Y}$ and $\mathrm{SiO}_{2 \text { (exc) }}$ content variability from the P. pacificus to M. extraordinarius zones in well ZY5 indicated that the productivity level of the $P$. pacificus zone was significantly higher than the $M$. extraordinarius zone. This was basically consistent with the vertical paleoproductivity variability characterized by the organic matter accumulation rate (OCAR) in well PY1 [10] and Datianba section [8] (Figure 7). The higher productivity in the P. pacificus zone indicated that higher nutrient inputs (e.g., $\mathrm{P}, \mathrm{Si}, \mathrm{Cu}$ and $\mathrm{Zn}$ ) led to the growth of primary producers (e.g., algae) in the inner Yangtze Sea, and consumer plankton (such as radiolarians) began to flourish. The atmospheric $\mathrm{O}_{2}$ levels were relatively low during the Late Ordovician [31]. Biogeochemical modeling has shown that, at low atmospheric $\mathrm{O}_{2}$ levels, dissolved $\mathrm{O}_{2}$ concentrations in surface seawater are controlled principally by local productivity through photosynthetic $\mathrm{O}_{2}$ release, with higher dissolved $\mathrm{O}_{2}$ contents in regions of higher productivity $[12,43]$. Therefore, this produced better-oxygenated conditions in the P. pacificus zone.

The decline of productivity in the M. extraordinarius zone was induced by a combination of: (1) formation of the Gondwana continental glacier, which led to a significant drop in global sea level [44,45], and (2) the sharp uplift of the Xiang'e Submarine High due to the increasing compression of Cathaysian plate to Yangtze plate [46], which resulted in a weak exchange rate between the inner and outer Yangtze Sea during this period [10]. This led to a decline of nutrient input. However, the relatively restricted water mass was conducive to the formation of relatively reduced water conditions [5].

\subsubsection{Provenance Composition of Shale and Paleoclimate Characteristics}

Nutrient and sulfate levels have important effects on the redox environment of the water column, and paleoclimate characteristics and provenance composition are the key factors controlling nutrient and sulfate fluxes. The source rock composition of fine-grained clastic rocks can be distinguished using main and trace elements in sediments. Elements such as Th, $\mathrm{Sc}$ and $\mathrm{Zr}$ are difficult to dissolve during geological processes such as migration, diagenesis and weathering, and are reliable indicators to distinguish the composition of source rocks $[47,48]$. When $\mathrm{TiO}_{2} / \mathrm{Zr}>200$ it indicates mafic igneous rocks, intermediate igneous rocks range between 55 and 195, and values lower than 55 are felsic igneous rocks [49]. 
The $\mathrm{TiO}_{2} / \mathrm{Zr}$ ratios for all shale samples ranged from 9.1 to 58.3 (mean 44.6), indicating that the source rocks were felsic igneous rocks (Figure 7a), such as granite and granodiorite. Correlations between the La-Te-Sc trigram and Th/Sc diagram of black shale samples in the study area (Figure $7 b, c$ ) also indicated that the source rocks were mostly granodiorite, and a few samples were granite. Therefore, the source rocks in the study area were mainly felsic igneous rocks, consistent with findings that the bedrock of the Yangtze craton is composed of granitic gneiss and amphibolite [50].

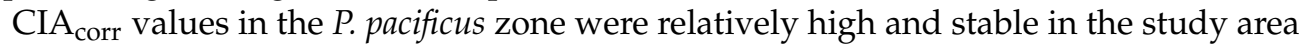
(Figure 7), ranging from 68.7 to 75.9 (mean 72.9), and suggest that source rocks underwent a moderate degree of chemical weathering under a warm and humid climate. CIA corr values declined, varying between 59.9 and 72.2 (mean $=67.6$ ) in the $M$. extraordinarius zone, indicating a gradual evolution from warm and humid climate to cold and dry climate conditions, and weaker chemical weathering intensity of the source area under relatively cooler and more arid conditions.

Within local and short time scales, water redox state is mainly controlled by the supply balance of organic matter and various oxidants within the region [51-53]. The composition of the source rock undergoing weathering will cause differences in the migration and enrichment of nutrient elements and oxidants to the ocean [12]. Late Ordovician shale in the study area was sourced from felsic igneous rocks, which would have required chemical weathering of the silicate mineral matrix to expose the contained sulfides to the atmosphere [52]. Therefore, we inferred that the difference in chemical weathering intensity was the main factor controlling sulfate weathering variability and nutrient flux in the inner Yangtze Sea during the P. pacificus zone and the M. extraordinarius zone.

As recently shown, volcanism plays an important role in global climate change [54]. The P. pacificus zone has experienced a warm and humid climate, it may be related to the global warming around the Katian-Hirnantian boundary caused by the greenhouse gases generated by the potential LIP-scale eruptions [55]. This is confirmed by recent reports of mercury enrichment and K-bentonites in South China, Laurencia and Poland during the late Ordovician [56-58]. The P. pacificus zone experienced a moderate degree of chemical weathering intensity in warm and humid climates. Sulfides such as pyrite accounted for a higher proportion than paste salts and other sulfates in the felsic source rocks. The sulfides were oxidized to produce sulfates in the process of chemical weathering during this time, which acted as a medium to accelerate the weathering of source rocks and were transported into the ocean by rivers. On the other hand, the abundance of nutrients from volcanic [58] and weathering sources entering the ocean is significantly enhanced, and the suitable temperature provides necessary conditions for the mass reproduction of hydrocarbon forming organisms (e.g., sponge spicule and graptolite) in surface sea-water [57], which stimulated the increase of oceanic primary productivity and promoted the expansion of surface oxic water environments. However, the M. extraordinarius zone was under cold and dry climatic conditions. Chemical weathering was weak due to low temperatures and limited sediment, and this cooling was accompanied by a reduction of the hydrological cycle, which caused the input of nutrients in the Inner Yangtze Sea to be significantly lower than in the P. pacificus zone, resulting in a decline in productivity. In addition, due to the coupling of global cooling and the uplift of the Xiang'e Submarine High, the inner Yangtze Sea became a stagnant and low-energy environment, which resulted in more reducing surface water conditions compared with the P. pacificus zone.

\subsection{Regional Comparison of Redox Environments}

The spatial patterns of redox variation in the Late Ordovician can be assessed within the biostratigraphic framework proposed by Chen et al. and Xi et al. [22,23]. This framework allows us to compare redox variation and explore further the mechanism of the difference in the spatial development of redox environment in the Inner Yangtze Sea during the $P$. pacificus zone and the $M$. extraordinarius zone. 


\subsubsection{The P. pacificus Zone}

The Xiushan Datianba section was deposited in the northeastern margin of the Qianzhong oldland (Figure $1 \mathrm{~b}$ ). The relatively high $\mathrm{Fe}_{\mathrm{py}} / \mathrm{Fe}_{\mathrm{HR}}$ profile in the Datianba section of the P. pacificus zone indicated deposition in an euxinic-dominated environment [8] (Figure 8). Water-column euxinic environment is generally controlled by the relative fluxes of $\mathrm{C}, \mathrm{S}$ and $\mathrm{Fe}$ in mid-depth waters, which is related to oceanic primary productivity, sulfate concentrations, and $\mathrm{Fe}_{\mathrm{HR}}$ supply $[53,59,60]$. The connection between inner and outer Yangtze seas (Figures $1 \mathrm{~b}$ and $9 \mathrm{a}$ ) was beneficial to the relatively high productivity level in its sedimentary history, and the pattern of the relatively high TOC content distribution through the upper P. pacificus zone of the Datianba section is similar to that from the other worldwide sites (e.g., Zbrza section in Poland, Arctic Canada) [61,62], which may be controlled by the "Boda" warming event. Marine productivity is sufficiently high (see Section 5.2.1), and a relatively low $\mathrm{Fe}_{\mathrm{HR}}$ fluxes (Datianba sections mean $=1.4 \%$, [8]) for the P. pacificus zone. Ample sulfate availability may be the main factor affecting the development of euxinia at mid-depth waters.

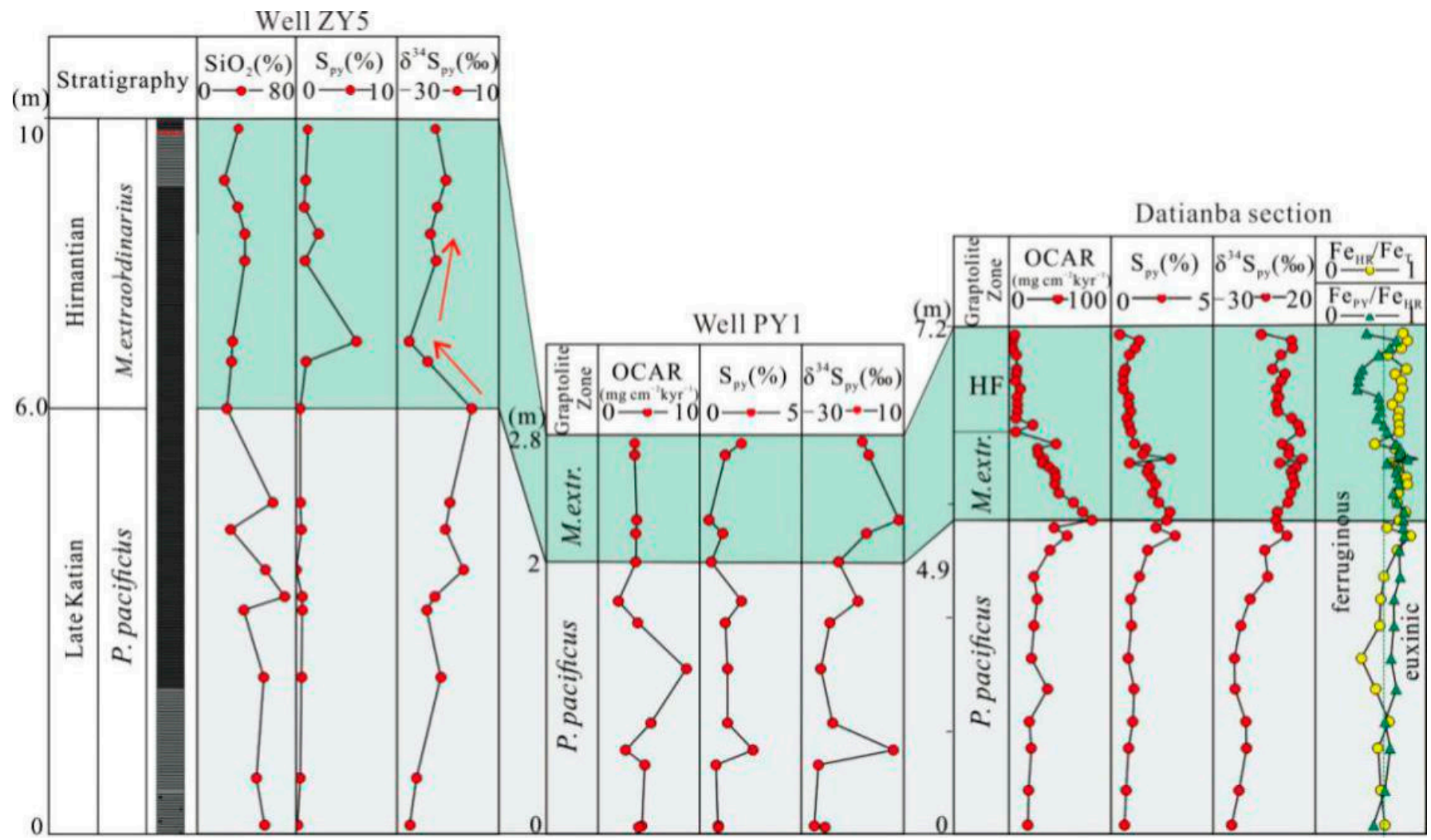

Figure 8. Comparison of productivity indicators, $S_{p y}, \delta^{34} S_{p y}$ in the Katian-Hirnantian shales of Well ZY5 in the study area, Fe-speciation data and $\delta^{34} S_{\text {py }}$ data for the Datianba sections are from [8], OCAR (mass accumulation rates of organic carbon) values and $\delta^{34} S_{\text {py }}$ data for the Well PY1 are from [10]. M. extra. = M. extraordinarius, HF = Hirnantia Fauna. 


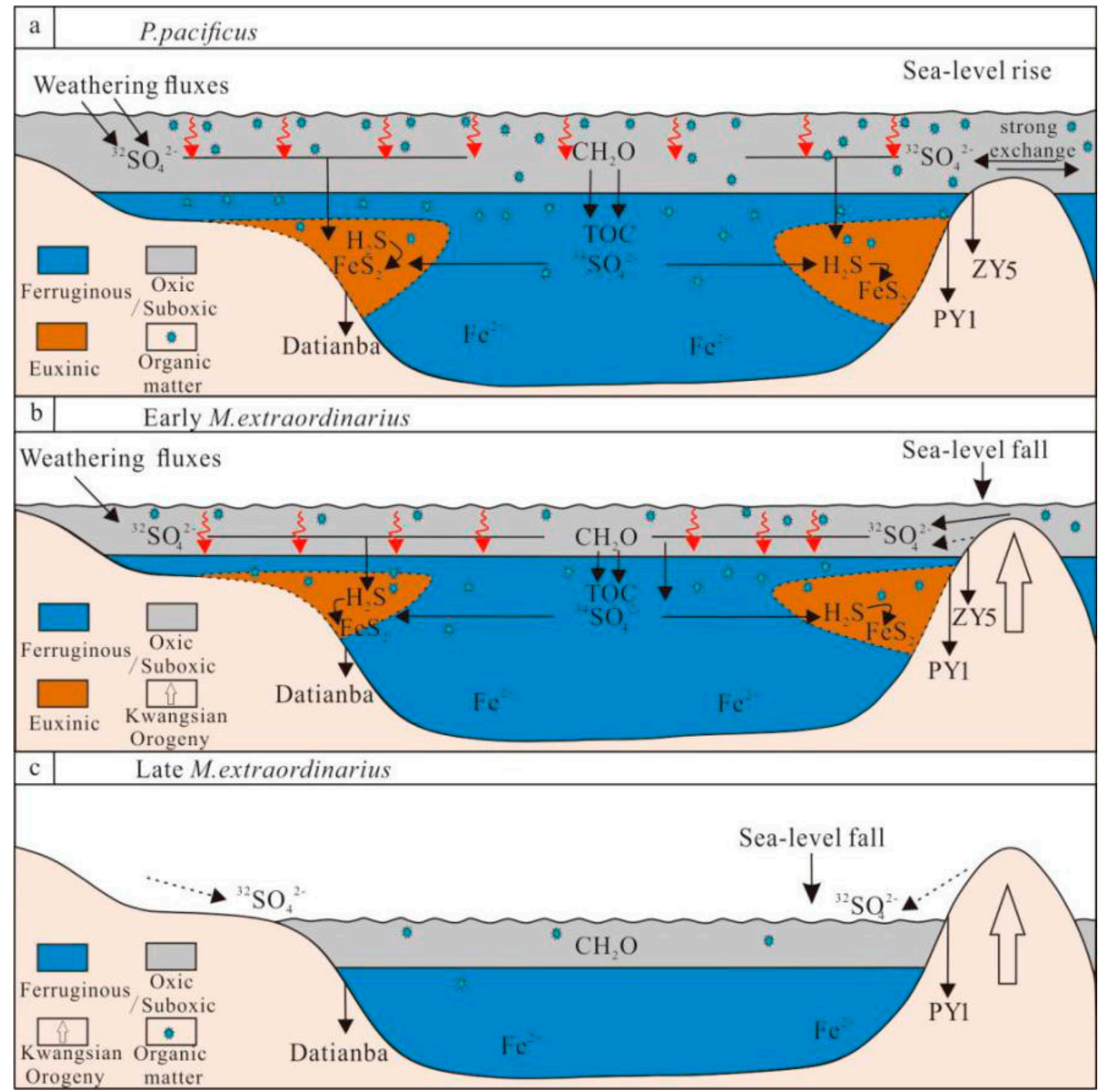

Figure 9. Schematic of a stratified redox model for the Late Ordovician inner Yangtze Sea. (a) oceanic redox structure in the P. pacificus zone; (b) oceanic redox structure in early the M.extraordinarius zone, (c) oceanic redox structure during the late M.extraordinarius zone. The sedimentary model is based on geochemical data from the Datianba section and Well PY1 [8,10].

Sulfate availability in a marine system can be investigated by using $\delta^{34} S_{\text {py }}[59,60]$. The availability of sulfate and organic matter controls the rate of bacterial sulfate reduction (BSR) and affects the composition of $\delta^{34} S_{\text {py }}$ in the BSR process [49]. Increasing productivity levels may consume sulfate and reduce the sulfur isotope fractionation between sulfate and sulfide $\left(\varepsilon_{\mathrm{BSR}}=\delta^{34} \mathrm{~S}_{\mathrm{SO}}{ }_{-} \delta^{34} \mathrm{~S}_{\mathrm{py}}\right)$, which causes the $\delta^{34} \mathrm{~S}_{\mathrm{py}}$ to become heavier [63]. Laboratory experiments have suggested that when sulfate concentrations fall below a biological threshold of $200 \mu \mathrm{M}$, the fractionation between sulphate and sulfide during $\mathrm{BSR}$ is reduced [64], leading to small or zero values for $\varepsilon_{\mathrm{BSR}}$ and thus isotopically heavier pyrites. The $\delta^{34} S_{\text {py }}$ values formed within the water column in the P. pacificus zone (e.g., PY1 and Datianba section) were relatively light (Figure 8). Wang et al. [65] suggested that the lighter conversion of $\delta^{34} S_{\text {py }}$ may have been controlled by a decrease in sulfate reduction rate or an increase in sulfate concentrations. The clear negative correlation between OCAR and $\delta^{34} S_{\text {py }}$ in well PY1 [10] indicated that high biological productivity was enough to drive 
sulfate reduction. Therefore, the most reasonable explanation may be that the seawater sulfate concentrations increased during BSR. An interpretation consistent with an increase of $S_{\text {py }}$ in the mid-depth waters of the study area (PY1 mean $=1.4 \%$, Datianba sections mean $=1.6 \%$ [10]). So ample sulfate accelerated the consumption of organic matter by BSR and produced $\mathrm{H}_{2} \mathrm{~S}$ accumulation in mid-depth water column, resulted to the formation and expansion of the euxinic water mass in the Datianba section [8]. Although $\delta^{34} S_{\text {py }}$ values in the P. pacificus zone were light in well ZY5 (average $=-14.5 \%$ ), it is always in an oxic water environment. Obviously, the sulfate availability may not be the main factor affecting the redox of Well ZY5.

According to the reconstructed paleotopography, well ZY5 was deposited in areas of shallow seas. Under the warm and humid climate conditions of the P. pacificus zone, the input of nutrients with a rise in sea level promoted the growth of algae and other organisms on the surface of the ocean, while plankton released a large amount of $\mathrm{O}_{2}$. In shallow seas, $\mathrm{O}_{2}$ takes precedence over $\mathrm{SO}_{4}{ }^{2-}$ oxidize the organic matter in the sinking process [66], and $\mathrm{O}_{2}$ has a reactive absorption effect on $\mathrm{H}_{2} \mathrm{~S}$ and inhibites BSR [67]. The consequent inadequated production of $\mathrm{H}_{2} \mathrm{~S}$ was not conducive to the persistently formation of the euxinic water mass to shallow areas, so well ZY5 water mass was an oxic environment (Figures 3 and 9a). Biogeochemical models have found that active biological activities caused the total respiratory $\mathrm{O}_{2}$ demand to exceed the supply of $\mathrm{O}_{2}$ to deep oceans through vertical mixing and diffusion [68], which caused sulfates to play a leading role in the process of organic matter degradation in mid-depth waters [67]. As a result, the euxinic waters environment of the inner Yangtze was sandwiched between the oxic ocean-surface layer and the deep ferruginous waters conditions, showing a tapering wedge towards the deep ocean (Figure 9a).

\subsubsection{The M. extraordinarius Zone}

The M. extraordinarius zone, $\mathrm{Fe}_{\mathrm{py}} / \mathrm{Fe}_{\mathrm{HR}}$ profile of the Xiushan Datianba section from relatively high in the early stage to low in middle and late stage, suggest that it was deposited in the euxinic to ferruginous transitions (Figures 8 and $9 b, c)$. Generally speaking, ferruginous conditions may be formed in marine systems characterized by low marine sulfate, low productivity and high $\mathrm{Fe}_{\mathrm{HR}}$. Due to the extensive euxinic environment formed in the P. pacificus zone of the inner Yangtze Sea [10] the sulfate concentrations were gradually consumed. In addition, climate cooling resulted in a significant drop in global sea level [45,47], and the intense uplift of the Xiang'e Submarine High during this period, resulting in a weak exchange rate between the inner and outer Yangtze Sea, thus limiting sulfate and nutrient resupply from both riverine and outer Yangtze seas sources. The inference was consistent with the heavy values of $\delta^{34} S_{\text {py }}$ and a decrease of $S_{\text {py }}$ (PY1 mean = $1.1 \%$, Datianba sections mean $=1.4 \%$ ) in the study, in addition, $\mathrm{SiO}_{2(\mathrm{exc})}$ and OCAR exhibits low values at $M$. extraordinarius zone (Figure 8). Therefore, The $\mathrm{H}_{2} \mathrm{~S}$ produced by BSR in mid-depth waters was insufficient to react $\mathrm{Fe}_{\mathrm{HR}}$ and allow it to accumulate [54]. This was consistent with the relatively high of $\mathrm{Fe}_{\mathrm{HR}}$ ratios during the M. extraordinarius zone (well ZY5 mean $=3.1 \%$, Datianba section mean $=2.2 \%$ ) (Figure 3). It was beneficial to the formation and expansion of ferruginous waters conditions in the Datianba section. However, well ZY5 was located on the flank of the inner Yangtze Sea, along the southwest margin of the the Xiang'e Submarine High (Figure 1b), and significant uplift of the Xiang'e Submarine High during this time resulted in relatively shallow water compared to coeval deposits of the Datianba section, which was key to the formation of an oxic water environment in well ZY5. However, the enhancement of water mass restriction caused the expansion of ferruginous waters conditions, which was one of the reasons for the enhanced of reduction degree of surface water compared with the P. pacificus zone. On the other hand, nutrients from continental chemical weathering sources were cut off during climate cooling and relative sea level decline. The low nutrient input resulted in the decline of paleoproductivity of bottom waters in shallow areas (see Section 5.2.1), which decreased $\mathrm{O}_{2}$ release intensity in the ocean surface waters, so water column environment of well ZY5 evolved from an 
oxic environment to enhanced water reduction degree (Figure 3; see Section 5.1). Therefore, with the shrinkage of euxinic and oxic water column conditions (Figure 9b), the water column of the inner Yangtze Sea evolved into an environment characterized by surface oxic waters and deep ferruginous waters conditions (Figure 9c).

\section{Conclusions}

Shale in well ZY5 was deposited in an oxic water column environment, and the reduction degree of water in the M. extraordinarius zone was stronger than in the P. pacificus zone. High productivity level controlled $\mathrm{O}_{2}$ release in the surface layer of the P. pacificus zone as well as the oxidation degree in the shallow water area of the inner Yangtze Sea. The decrease in productivity and the relatively restricted water mass of the inner Yangtze Sea controlled the formation of relatively reduced water conditions in the M. extraordinarius zone.

The change in CIA values from the P.pacificus zone to the M. extraordinarius zone showed that paleoclimate conditions changed from warm and humid to cold and dry in the study area. The geochemistry characteristics of the Late Ordovician Datianba sections and well ZY5 on the Upper Yangtze platform were useful in illustrating the redox evolution of the inner Yangtze Sea. In the P. pacificus zone, warm and humid climatic conditions drove the inner Yangtze Sea's high productivity levels, sulfate fluxes and low reactive iron flux, which promoted the spread of surface oxic water conditions and mid-depth euxinic water column conditions. The M. extraordinarius zone, the cold and dry climate and the uplift of the Xiang'e Submarine High co-contributed to the relative sea level decline, causing low productivity and sulfate flux, and high reactive iron flux, which promoted the expansion of mid-depth ferruginous water and the shrinkage of oxic surface water. The regional paleogeographic framework is an important reason for the spatial difference of redox environment.

Supplementary Materials: The following are available online at https://www.mdpi.com/article/ $10.3390 / \min 11070710 / s 1$, Table S1: Key geochemical data for marine redox evaluation and trace element at the Well ZY5, Table S2: Key geochemical data for calculation of marine productivity fluxes, CIA and $S$ isotopic compositions at the Well ZY5.

Author Contributions: D.L., Z.X., Y.Y., S.T. and B.Z. conceived and designed the experiments; D.L., Z.X., B.Z. and Y.Y. performed the experiments and data curation; D.L., Z.X. and S.T. wrote and revised the paper. All authors have read and agreed to the published version of the manuscript.

Funding: This paper was supported by the National Science and Technology Major Project of China (Grant No. 2017ZX05035).

Data Availability Statement: Data for this study are presented in the supplementary materials.

Conflicts of Interest: The authors declare no conflict of interest.

\section{References}

1. Chen, X.; Rong, J.; Li, Y.; Boucot, A.J. Facies patterns and geography of the Yangtze region, south China, through the Ordovician and silurian transition. Palaeogeogr. Palaeoclimatol. Palaeoecol. 2004, 204, 353-372.

2. Zhou, L.; Algeo, T.J.; Shen, J.; Hu, Z.; Gong, H.; Xie, S.; Huang, J.; Gao, S. Changes in marine productivity and redox conditions during the Late Ordovician Hirnantian glaciation. Palaeogeogr. Palaeoclimatol. Palaeoecol. 2015, 420, 223-234. [CrossRef]

3. Zou, C.; Qiu, Z.; Poulton, S.W.; Dong, D.; Wang, H.; Chen, D.; Lu, B.; Shi, Z.; Tao, H. Ocean euxinia and climate change "double whammy" drove the Late Ordovician mass extinction. Geology 2018, 46, 535-538. [CrossRef]

4. Zou, C.; Zhu, R.; Chen, Z.-Q.; Ogg, J.G.; Wu, S.; Dong, D.; Qiu, Z.; Wang, Y.; Wang, L.; Lin, S.; et al. Organic-matter-rich shales of China. Earth Sci. Rev. 2019, 189, 51-78. [CrossRef]

5. Li, Y.; Zhang, T.; Ellis, G.S.; Shao, D. Depositional environment and organic matter accumulation of Upper Ordovician-Lower Silurian marine shale in the Upper Yangtze Platform, South China. Palaeogeogr. Palaeoclimatol. Palaeoecol. 2017, 466, 252-264. [CrossRef]

6. Wu, J.J.; Liang, C.; Hu, Z.Q.; Yang, R.C.; Xie, J.; Wang, R.Y.; Zhao, J.H. Sedimentation mechanisms and enrichment of organic matter in the Ordovician Wufeng Formation-Silurian Longmaxi Formation in the Sichuan Basin. Mar. Petrol. Geol. 2019, 101, 556-565. [CrossRef] 
7. Jin, C.S.; Liao, Z.W.; Tang, Y.J. Sea-level changes control organic matter accumulation in the Longmaxi shales of southeastern Chongqing, China. Mar. Pet. Geol. 2020, 119, 104478. [CrossRef]

8. Liu, Y.; Li, C.; Algeo, T.J.; Fan, J.; Peng, P. Global and regional controls on marine redox changes across the Ordovician-Silurian boundary in South China. Palaeogeogr. Palaeoclimatol. Palaeoecol. 2016, 463, 180-191. [CrossRef]

9. Ahm, A.-S.C.; Bjerrum, C.J.; Hammarlund, E.U. Disentangling the record of diagenesis, local redox conditions, and global seawater chemistry during the latest Ordovician glaciation. Earth Planet. Sci. Lett. 2017, 459, 145-156. [CrossRef]

10. Li, N.; Li, C.; Fan, J.; Algeo, T.J.; Yan, D.; Zhu, G.; Wu, S.; Tang, S.; Cheng, M.; Jin, C. Sulfate-controlled marine euxinia in the semi-restricted inner Yangtze Sea (South China) during the Ordovician-Silurian transition. Palaeogeogr. Palaeoclimatol. Palaeoecol. 2019, 534, 109281. [CrossRef]

11. Shang, F.; Zhu, Y.; Hu, Q.; Wang, Y.; Li, Y.; Li, W.; Liu, R.; Gao, H. Factors controlling organic-matter accumulation in the Upper Ordovician-Lower Silurian organic rich shale on the northeast margin of the Upper Yangtze platform: Evidence from petrographic and geochemical proxies. Mar. Pet. Geol. 2020, 121, 104597. [CrossRef]

12. Wang, H.; Zhang, Z.; Li, C.; Algeo, T.J.; Cheng, M.; Wang, W. Spatiotemporal redox heterogeneity and transient marine shelf oxygenation in the Mesoproterozoic ocean. Geochim. Cosmochim. Acta 2020, 270, 201-217. [CrossRef]

13. Tribovillard, N.; Algeo, T.J.; Lyons, T.; Riboulleau, A. Traceemetals as paleoredox and paleoproductivity proxies: An update. Chem. Geol. 2006, 232, 12-32. [CrossRef]

14. Algeo, T.J.; Maynard, J.B. Trace-Element behavior and Redox Facies in Core shales of Upper Pennsylvanian Kansas-type cyclothems. Chem. Geol. 2004, 206, 289-318. [CrossRef]

15. Poulton, S.W.; Canfield, D.E. Ferruginous conditions: A dominant feature of the ocean through Earth's history. Elements 2011, 7, 107-112. [CrossRef]

16. Wilkin, R.T.; Arthur, M.A.; Dean, W.E. History of water-column anoxia in the Black Sea indicated by pyrite framboid size distributions. Earth Planet. Sci. Lett. 1997, 148, 517-525. [CrossRef]

17. Metcalfe, I. Late Palaeozoic and Mesozoic palaeogeography of eastern Pangaea and Tethys. Glob. Environ. Resour. Mem. 1994, 17, 97-111.

18. Chen, X. Onset of the Kwangsian Orogeny as evidenced by biofacies and lithofacies. Sci. China Earth Sci. 2012, 55, 1592-1600. [CrossRef]

19. Chen, X. Influence of the Late Ordovician glaciation on basin configuration of the Yangtze Platform in China. Lethaia 1984, 17, 51-59.

20. Liu, Y.; Li, C.; Fan, J.; Peng, P.; Algeo, T.J. Elevated marine productivity triggered nitrogen limitation on the Yangtze Platform (South China) during the Ordovician-Silurian transition. Palaeogeogr. Palaeoclimatol. Palaeoecol. 2020, 554, 109833. [CrossRef]

21. Chen, X.; Fan, J.; Chen, Q.; Tang, L.; Hou, X. Toward a stepwise Kwangsian orogeny. Sci. China Earth Sci. 2014, 57, 379-387. [CrossRef]

22. Chen, X.; Rong, J.; Fan, J. A global correlation of zones across the Ordovician-Silurian boundary. Acta Palaeont. Sin. 2000, 39, 100-114.

23. Xi, Z.; Tang, S.; Lash, G.G.; Zhang, B.; Lin, D. Geochemical characteristics of organic carbon and pyrite sulfur in OrdovicianSilurian transition shales in the Yangtze Platform, South China: Implications for the depositional environment. Palaeogeogr. Palaeoclimatol. Palaeoecol. 2020, 563, 110173. [CrossRef]

24. Xi, Z.D.; Tang, S.H.; Li, J.; Zhang, Z.; Xiao, H. Pore characterization and the controls of organic matter and quartz on pore structure: Case study of the Niutitang Formation of northern Guizhou Province, South China. J. Nat. Gas Sci. Eng. 2019, 61, 18-31. [CrossRef]

25. Xi, Z.D.; Tang, S.H.; Zhang, S.H.; Ye, Y.P. Factors controlling organic matter accumulation in the Wufeng-Longmaxi Formations in northwestern Hunan Province: Insights from major/trace elements and shale composition. Energy Fuel 2020, 34, 4139-4152. [CrossRef]

26. Canfield, D.E.; Raiswell, R.; Westrich, J.T.; Reaves, C.M.; Berner, R.A. The use of chromium reduction in the analysis of reduced inorganic sulfur in sediments and shales. Chem. Geol. 1986, 54, 149-155. [CrossRef]

27. Poulton, S.W.; Canfield, D. Development of a sequential extraction procedure foriron: Implications for iron partitioning in continentally derived particulates. Chem. Geol. 2005, 214, 209-221. [CrossRef]

28. Helz, G.R.; Bura-Nakić, E.; Mikac, N.; Ciglenečki, I. New model for molybdenum behavior in euxinic waters. Chem. Geol. 2011, 284, 323-332. [CrossRef]

29. Scott, C.; Lyons, T.W. Contrasting molybdenum cycling and isotopic properties in euxinic versus non-euxinic sediments and sedimentary rocks: Refining the paleoproxies. Chem. Geol. 2012, 324, 19-27. [CrossRef]

30. Bryn, J.; David, A. Manning, Comparison of geochemical indices used for the interpretation of palaeoredox conditions in ancient mudstones. Chem. Geol. 1994, 111, 111-129.

31. Algeo, T.J.; Ingall, E. Sedimentary $\mathrm{C}_{\mathrm{org}}$ :P ratios, paleocean ventilation, and Phanerozoic atmospheric $\mathrm{pO}_{2}$. Palaeogeogr. Palaeoclimatol. Palaeoecol. 2007, 256, 130-155. [CrossRef]

32. Wilkin, R.T.; Barnes, H.L.; Brantley, S.L. The size distribution of framboidal pyrite in modern sediments: An indicator of redox conditions. Geochim. Cosmochim. Acta 1996, 60, 3897-3912. [CrossRef] 
33. Khan, M.Z.; Feng, Q.; Zhang, K.; Guo, W. Biogenic silica and organic carbon fluxes provide evidence of enhanced marine productivity in the upper Ordovician-lower silurian of South China. Palaeogeogr. Palaeoclimatol. Palaeoecol. 2019, $534,109278$. [CrossRef]

34. Morford, J.L.; Emerson, S. The geochemistry of redox sensitive trace metals in sediments. Geochim. Cosmochim. Acta 1999, 63, 1735-1750. [CrossRef]

35. Chen, H.; Xie, X.; Li, H.; Su, P.; Peng, W.; Hu, C. Permian Marine source rocks in Shangsi section of Sichuan Province were evaluated by using alternative indices of palaeo-oxygen facies and palaeo-productivity. J. Palaeogeogr. 2010, 12, 324-333.

36. Michalopoulos, P.; Aller, R.C. Early diagenesis of biogenic silica in the Amazondelta: Alteration, authigenic clay formation, and storage. Geochim. Cosmochim. Acta 2004, 68, 1061-1085. [CrossRef]

37. Nesbitt, H.W.; Young, G.M. Early Proterozoic climates and plate motions inferred from major element chemistry of lutites. Nature 1982, 299, 715-717. [CrossRef]

38. Nesbitt, H.W.; Young, G.M. Prediction of some weathering trends of plutonic and volcanic rocks based on thermodynamic and kinetic considerations. Geochim. Cosmochim. Acta 1984, 48, 1523-1534. [CrossRef]

39. Young, G.M.; Nesbitt, H.W. Paleoclimatology and provenance of the glaciogenic Gowganda Formation (Paleoproterozoic), Ontario, Canada: A chemostratigraphic approach. GSA Bull. 1999, 111, 264-274. [CrossRef]

40. Fedo, C.M.; Nesbitt, H.W.; Young, G.M. Unraveling the effects of potassium metasomatism in sedimentary rocks and paleosols, with implications for paleo-weathering conditions and provenance. Geology 1995, 23, 921-924. [CrossRef]

41. Mclennan, S.M. Weathering and global denudation. J. Geol. 1993, 101, 295-303. [CrossRef]

42. Panahi, A.; Young, G.M.; Rainbird, R.H. Behavior of major and trace elements (including REE) during Paleoproterozoic pedogenesis and diagenetic alteration of an Archean granite near Ville Marie, Québec, Canada. Geochim. Cosmochim. Acta 2000, 64, 2199-2220. [CrossRef]

43. Reinhard, C.T.; Planavsky, N.J.; Olson, S.L.; Lyons, T.W.; Erwin, D.H. Earth's oxygen cycle and the evolution of animal life. Proc. Natl. Acad. Sci. USA 2016, 113, 8933-8938. [CrossRef] [PubMed]

44. Saltzman, M.R.; Young, S.A. Long-lived glaciation in the Late Ordovician? Isotopic and sequence-stratigraphic evidence from western Laurentia. Geology 2005, 33, 109-112. [CrossRef]

45. Wang, K.; Orth, C.J.; Attrep, M.; Chatterton, B.; Wang, X.; Li, J. The great latest Ordovician extinction on the South China Plate: Chemostratigraphic studies of the Ordovician-Silurian boundary interval on the Yangtze Platform. Palaeogeogr. Palaeoclimatol. Palaeoecol. 1993, 104, 61-79. [CrossRef]

46. Wang, Y.; Rong, J.; Zhan, R.; Huang, B.; Wu, R.; Wang, G. On the Ordovician-Silurian boundary strata in southwestern Hubei, and the Yichang Uplift. J. Stratigr. 2013, 37, 264-274.

47. McLennan, S.M.; Hemming, S.R.; Taylor, S.R.; Eriksson, K.A. Early Proterozoic crustal evolution: Geochemical and Nd-Pb isotopic evidence from metasedimentary rocks, southwestern North America. Geochim. Cosmochim. Acta 1995, 59, 1153-1177. [CrossRef]

48. Cullers, R.L.; Podkovyrov, V.N. Geochemistry of the Mesoproterozoic Lakhanda shales in southeastern Yakutia, Russia: Implications for mineralogical and provenance control, and recycling. Precambrian Res. 2000, 104, 77-93. [CrossRef]

49. Hayashi, K.; Fujisawa, H.; Holland, H.D.; Ohmoto, H. Geochemistry of $1.9 \sim$ Ga sedimentary rocks from northeastern Labrador, Canada. Geochim. Cosmochim. Acta 1997, 61, 4115-4137. [CrossRef]

50. Gu, X.X.; Liu, J.M.; Zheng, M.H.; Tang, J.X.; Qi, L. Provenance and Tectonic Setting of the Proterozoic Turbidites in Hunan, South China: Geochemical Evidence. J. Sediment. Res. 2002, 72, 393-407. [CrossRef]

51. Johnston, D.T.; Poulton, S.W.; Dehler, C.; Porter, S.; Husson, J.; Canfield, D.E.; Knoll, A.H. An emerging picture of Neoproterozoic ocean chemistry: Insights from the Chuar Group, Grand Canyon, USA. Earth Planet Sci. Lett. 2010, 290, 64-73. [CrossRef]

52. Li, C.; Love, G.D.; Lyons, T.W.; Scott, C.T.; Feng, L.; Huang, J.; Chang, H.; Zhang, Q.; Chu, X. Evidence for a redox stratified Cryogenian marine basin, Datangpo Formation, South China. Earth Planet Sci. Lett. 2012, 331-332, 246-256. [CrossRef]

53. Feng, L.; Li, C.; Huang, J.; Chang, H.; Chu, X. A sulfate control on marine mid-depth euxinia on the early Cambrian(ca. 529-521 Ma) Yangtze platform, South China. Precambrian Res. 2014, 246, 123-133. [CrossRef]

54. McKenzie, N.R.; Horton, B.K.; Loomis, S.E.; Stockli, D.F.; Planavsky, N.J.; Lee, C.T.A. Continental arc volcanism as the principal driver of icehouse-greenhouse variability. Science 2016, 352, 444-447. [CrossRef] [PubMed]

55. Bond David, P.G.; Grasby Stephen, E. Late Ordovician mass extinction caused by volcanism, warming, and anoxia, not cooling and glaciation. Geology 2020, 48, 777-781. [CrossRef]

56. Jones, D.S.; Martini, A.M.; Fike, D.A.; Kaiho, K. A volcanic trigger for the Late Ordovician mass extinction? Mercury data from south China and Laurentia. Geology 2017, 45, 631-634. [CrossRef]

57. Wu, L.; Lu, Y.; Jiang, S.; Liu, X.; Liu, Z.; Lu, Y. Relationship between the origin of organic-rich shale and geological events of the Upper Ordovician-Lower Silurian in the Upper Yangtze area. Mar. Pet. Geol. 2019, 102, 74-85. [CrossRef]

58. Smolarek-Lach, J.; Marynowski, L.; Trela, W.; Wignall, P.B. Mercury Spikes Indicate a Volcanic Trigger for the Late Ordovician Mass Extinction Event: An Example from a Deep Shelf of the Peri-Baltic Region. Sci. Rep. 2019, 9, 3139. [CrossRef]

59. Raiswell, R.; Canfield, D.E. The iron biogeochemical cycle past and present. Geochem. Perspect. 2012, 1, 1-220. [CrossRef]

60. Lei, L.; Shen, J.; Li, C.; Algeo, T.J.; Chen, Z.; Feng, Q.; Cheng, M.; Jin, C.; Huang, J. Controls on regional marine redox evolution during Permian-Triassic transition in South China. Palaeogeogr. Palaeoclimatol. Palaeoecol. 2017, 486, 17-32. [CrossRef]

61. Smolarek, J.; Marynowski, L.; Trela, W.; Kujawski, P.; Bernd, R.T. Simoneit, Redox conditions and marine microbial community changes during the end-Ordovician mass extinction event. Glob. Planet. Chang. 2017, 149, 105-122. [CrossRef] 
62. Melchin, M.M.; Mitchell, C.E.; Holmden, C.; Štorch, P. Environmental changes in the Late Ordovician-early Silurian: Review and new insights from black shales and nitrogen isotopes. Geol. Soc. Am. Bull. 2013, 125, 1635-1670. [CrossRef]

63. Leavitt, W.D.; Halevy, I.; Bradley, A.S.; Johnston, D.T. Influence of sulfate reduction rates on the Phanerozoic sulfur isotope record. Proc. Natl. Acad. Sci. USA 2013, 110, 11244-11249. [CrossRef] [PubMed]

64. Habicht, K.S.; Gade, M.; Thamdrup, B.; Berg, P.; Canfield, D.E. Calibration of sulfate levels in the Archean ocean. Science 2002, 298, 2372-2374. [CrossRef] [PubMed]

65. Wang, X.; Zhang, S.; Wang, H.; Bjerrum, C.J.; Hammarlund, E.U.; Haxen, E.R.; Su, J.; Wang, Y.; Canfield, D.E. Oxygen, climate and the chemical evolution of a 1400 million year old tropical marine setting. Am. J. Sci. 2017, 317, 861-900. [CrossRef]

66. Libes, S.M. Introduction to Marine Biogeochemistry; Elsevier: Amsterdam, The Netherlands, 2009.

67. Anbar, A.D.; Knoll, A.H. Proterozoic ocean chemistry and evolution: A bioinorganic bridge. Science 2002, $297,1137-1142$. [CrossRef]

68. Lyons, T.W.; Reinhard, C.T.; Planavsky, N.J. The rise of oxygen in Earth's early ocean and atmosphere. Nature 2014, 506, 307-315. [CrossRef] [PubMed] 